\title{
Rhyolitic volcanism of the central Snake River Plain A review
}

\author{
Journal Article \\ Author(s): \\ Ellis, B. S.; Wolff, J. A.; Boroughs, S.; Mark, D. F.; Starkel, W. A.; Bonnichsen, B. \\ Publication date: \\ 2013-07 \\ Permanent link: \\ https://doi.org/10.3929/ethz-b-000071125 \\ Rights / license: \\ In Copyright - Non-Commercial Use Permitted \\ Originally published in: \\ Bulletin of Volcanology 75(8), https://doi.org/10.1007/s00445-013-0745-y
}




\title{
Rhyolitic volcanism of the central Snake River Plain: a review
}

\author{
B. S. Ellis • J. A. Wolff • S. Boroughs • D. F. Mark • \\ W. A. Starkel • B. Bonnichsen
}

Received: 5 April 2013 / Accepted: 24 June 2013 /Published online: 20 July 2013

(C) Springer-Verlag Berlin Heidelberg 2013

\begin{abstract}
The central Snake River Plain (CSRP) of southern Idaho and northern Nevada, USA, forms part of the Columbia River-Yellowstone large igneous province. Volcanic rocks of the province are compositionally bimodal (basalt-rhyolite), and the rhyolites produce a broadly time-transgressive record of a hotspot which is currently located under Yellowstone. Snake River Plain rhyolites represent hot $\left(>850{ }^{\circ} \mathrm{C}\right)$, dry magmas and have field characteristics consistent with high emplacement temperatures. Individual ignimbrite sheets reach $1,000 \mathrm{~km}^{3}$ and exhibit little to no compositional zonation on a large scale but reveal considerable complexity on a crystal scale, particularly with regard to pyroxene compositions. Multiple pyroxene compositions may exist in a single ignimbrite which, along with multiple glass compositions in widely dispersed fallout tephra, suggests complex storage of rhyolite prior to eruption. Unlike most igneous rocks, the mineral cargo of the CSRP rhyolites exhibits little isotopic variability, with unimodal ${ }^{87} \mathrm{Sr} /{ }^{86} \mathrm{Sr}$ values returned from plagioclase grains inferred to represent the combination of strong crystal-melt coupling and rapid diffusional re-equilibriation. All the rhyolites within the CSRP have a characteristic low- $\delta^{18} \mathrm{O}$
\end{abstract}

Editorial responsibility: S. Self

B. S. Ellis $(\bowtie)$

Institute for Geochemistry and Petrology, ETH Zurich,

NW Clausiusstrasse 25, 8092 Zurich, Switzerland

e-mail: ben.ellis@erdw.ethz.ch

J. A. Wolff $\cdot$ S. Boroughs $\cdot$ W. A. Starkel

School of the Environment, Washington State University,

Pullman, WA 99164, USA

D. F. Mark

NERC Argon Isotope Facility, Scottish Universities Environmental

Research Centre (SUERC), Rankine Avenue, East Kilbride,

Scotland G75 0QF, UK

B. Bonnichsen

927 East 7th Street, Moscow, ID, USA signature; with $>20,000 \mathrm{~km}^{3}$ of rhyolite exhibiting this depletion, the CSRP represents the largest low $-\delta^{18} \mathrm{O}$ province on Earth. The low- ${ }^{18} \mathrm{O}$ nature of the rhyolites requires assimilation of hydrothermally altered materials which may be from altered Eocene batholithic rocks or from down-dropped intracaldera tuffs. The wide range of crustal assimilants, with highly variable radiogenic isotope characteristics, available in the CSRP is permissive of a variety of petrogenetic models based on radiogenic isotopic data.

Keywords Snake River Plain · Rhyolite · Bimodal · Ignimbrite $\cdot$ Low $\delta^{18} \mathrm{O}$

\section{Introduction}

For the past $\sim 16.7 \mathrm{Ma}$, the inland northwest of North America has been the site of a large igneous province. Activity began with the voluminous outpouring of basalt in the Columbia River Basalt Group from sources in eastern Oregon, prior to rapid northward migration and the development of a fissure system on the Idaho-Oregon and Idaho-Washington borders (Swanson et al. 1979; Swisher et al. 1990; Geist and Richards 1993; Camp 1995; Hooper et al. 2002; Camp and Ross 2004; Wolff et al. 2008). Although basaltic volcanism in Washington and northern Idaho continued up to $\sim 6 \mathrm{Ma}$ (Reidel et al. 2013), the majority of material was erupted between $\sim 16.7$ and $16 \mathrm{Ma}$ in the Steens, Imnaha and Grande Ronde Formations (Hooper et al. (2007) and references therein; Jarboe et al. 2008; 2010). Broadly synchronously, silicic magma was erupting over a wide region of southern Oregon and northern Nevada (Brueseke et al. 2008; Shervais and Hanan 2008; Brueseke and Hart 2009; Coble and Mahood 2012). Silicic volcanism remained dispersed until $\sim 14 \mathrm{Ma}$ when it became more focussed along the near-linear track, extending from southwesternmost Idaho along the central and eastern Snake River Plain and culminating in the present-day Yellowstone 
plateau (Fig. 1). During its development, the central Snake River Plain (CSRP) likely was extending in an ENE-WSW direction, parallel to the elongation of the Yellowstone-eastern Snake River Plain hotspot trend and to the proposed drift direction of the North American continent. Evidence for this includes numerous normal faults and basalt dikes with NNW to WNW strikes within the CSRP, approximately perpendicular to the eastern Snake River Plain elongation, and to the NE-SW direction in which the western SRP rift was being widened as the CSRP developed.

The Snake River Plain represents one of the best known compositionally bimodal (basalt-rhyolite) volcanic provinces, with silicic volcanism broadly time-transgressive from southern Idaho to Wyoming (Armstrong et al. 1975; Pierce and Morgan 1992), although this relationship is not perfectly monotonic in detail (Bonnichsen et al. 2008), and there are major exceptions to the age progression such as the Arbon Valley Tuff (Kellogg et al. 1994) and the Magic Reservoir Eruptive Centre (Leeman 1982; Honjo and Leeman 1987). Despite the broad-scale relationship between age and longitude of silicic volcanism, basaltic volcanism in the Snake River Plain (SRP), which generally followed silicic volcanism at any location, does not exhibit the same timetransgressive behaviour (Bonnichsen and Godchaux 2002). To the east, the High Lava Plains of central Oregon show a similar trend of time-transgressive behaviour in silicic volcanic rocks, although with younging occurring to the west which has been attributed to the flow of plume material westward from the cratonic margin (Camp and Ross 2004; Jordan et al. 2004).

Silicic volcanism is currently focussed at the Yellowstone volcanic field, which sits some $600 \mathrm{~m}$ higher than the surrounding Rocky Mountains and is associated with a heat flow anomaly some 30-40 times that of the surrounding nonvolcanic regions (Lowenstern and Hurwitz 2008). A deepseated seismic low-velocity zone, interpreted by many workers as a mantle plume, has been imaged beneath Yellowstone at the eastern terminus of the province (Yuan and Dueker 2005; Schutt et al. 2008; Obrebski et al. 2010; Schmandt et al. 2012), in addition to a shallow, hot, sheet-like upwelling beneath the Snake River Plain for much of its length (Wagner et al. 2010; James et al. 2011; Schmandt et al. 2012). A mantle plume has been both invoked and refuted as the source for the Columbia River basalts (e.g. Hooper et al. 2007 and the ensuing discussion-in-print). A number of studies have questioned the nature and even existence of the proposed plume beneath the Yellowstone volcanic field; on the basis of inferred mantle temperature, Leeman et al. (2009) suggested that the thermal anomaly under Yellowstone was significantly less than those under other 'hotspots'. Via numerical modelling, Manea et al. (2009) concluded that solely plume-driven thermal erosion of the lithosphere would be insufficient to cause decompression melting and preferred Snake River magmas to be derived from melting of the subcontinental lithospheric mantle. Using seismic imaging, James et al. (2011) inferred that the breakup of the subducting Farallon slab and subsequent mantle upwellings

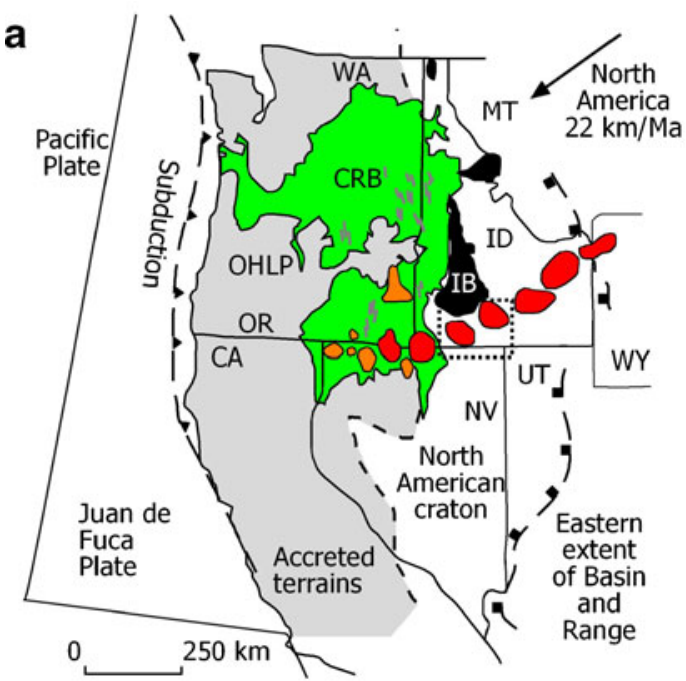

Fig. 1 Location of the Snake River Plain. a Regional map showing the extent of the Columbia River-Yellowstone magmatic province (after Perkins and Nash (2002)). The dotted square represents the location of the DEM in b. $C R B$ Columbia River basalts, OHLP Oregon High Lava Plains, $I B$ Idaho batholith. The red shapes represent the proposed eruptive centres of silicic volcanism along the Snake River Plain, the orange shapes represent some of the early silicic volcanism associated with the Columbia River-Yellowstone province, the green area represents the extent of the Columbia River flood basalts and the grey lines represent

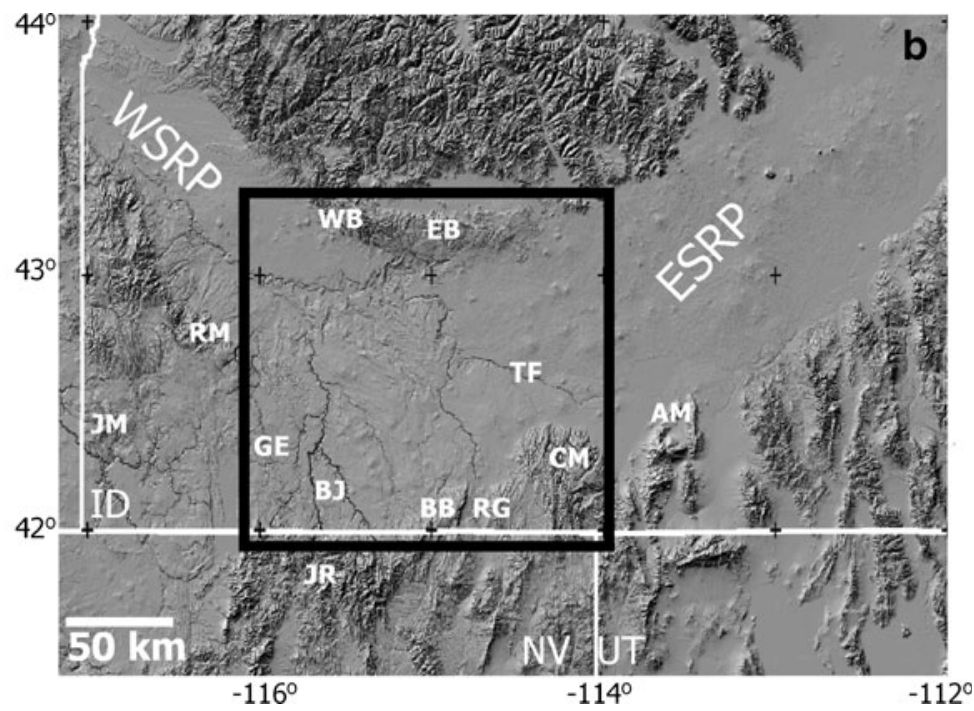

CRB dike swarms. b Location of the central Snake River Plain (black square) in southern Idaho and northern Nevada. Abbreviations relate to areas where the rhyolitic successions have been studied: $A M$ Albion Mountains, $B B$ Browns Bench, $B J$ Bruneau-Jarbidge, $C M$ Cassia Mountains, $E B$ East Bennett Mountains, ESRP Eastern Snake River Plain, $G E$ Grasmere Escarpment, $J M$ Juniper Mountain, $J R$ Jarbidge Rhyolite, $R G$ Rogerson Graben, $R M$ Rough Mountain, $T F$ Twin Falls, $W B$ West Bennett Mountains, WSRP Western Snake River Plain. The location of the McDermitt caldera is shown in Fig. 13 
around the fragmented slab were the cause of SRP volcanism. Alternatively, non-plume explanations include unusually copius back-arc volcanism, regional extension and other dominantly upper mantle origins related to plate tectonics (Carlson and Hart 1988; Smith 1992; Christiansen et al. 2002; Hales et al. 2005; James et al. 2011; Liu and Stegman 2012; Long et al. 2012). The ultimate cause of volcanism within the Yellowstone-Snake River Plain province as a whole remains contentious and addressing all the arguments in detail is beyond the scope of this review which summarises what is currently known about the Miocene silicic volcanism in the central Snake River Plain.

\section{The central Snake River Plain}

This review is primarily concerned with the rhyolites of the central Snake River Plain which have a combination of physical characteristics that are significantly different from "common" rhyolites in other volcanic provinces. The CSRP rhyolites cover an area from the Grasmere Escarpment in the west to the vicinity of the city of Twin Falls in the east (Fig. 1). The rhyolites were erupted between c. 14 and $6 \mathrm{Ma}$ and are overlain by volumetrically subordinate basalts of broadly tholeiitic affinity (Bonnichsen and Godchaux 2002). The rhyolites are those referred to by Malde and Powers (1962) as the Idavada Volcanics and described as 'non-mineralized silicic volcanic rocks, chiefly welded ash flows but including some bedded vitric tuffs and lava flows... which contain no phenocrysts of hornblende or biotite'. CSRP rhyolite is mostly exposed to the north and south of the plain itself where it forms thick (up to $500 \mathrm{~m}$ ) successions of ignimbrites and lavas intercalated with minor nonwelded pyroclastic deposits, reworked volcanic material and palaeosols and rare basalts (Bonnichsen et al. 2008; Branney et al. 2008; Davis and Ellis 2010). In many cases, rhyolitic ignimbrites are only exposed in steep-sided canyons or fault scarps which may be separated by tens of kilometres along the margins of the plain and by $>100 \mathrm{~km}$ across the plain. The rhyolitic volcanics overlie rocks of varying ages at the margins of the region, including Eocene rhyodacites in northern Nevada (Bernt and Bonnichsen 1982), Permian limestone in the Cassia Mountains (Williams et al. 1999) or Cretaceous and Eocene granites of the Idaho batholith (Kiilsgaard et al. 2001).

\section{Physical characteristics}

The rhyolitic lavas and ignimbrites of the CSRP have an association of lithofacies so distinct and different from those of common rhyolites that they have been defined as a new category of volcanic activity, 'Snake River (SR)-type' volcanism (Branney et al. 2008). The details of the unusual lithofacies are summarised here-see Branney et al. (2008) for a comprehensive treatment.

The ignimbrites exhibit a bimodality of welding with both intensely welded and non-welded ignimbrites present (Fig. 2), but moderately welded, eutaxitic ignimbrites are absent. The welded ignimbrites are of high grade and commonly intensely welded throughout; even in cases where they are thin to only a few metres (e.g. Castleford Crossing Ignimbrite, House Creek ignimbrite; Branney et al. 2008). In a thin section, pyroclastic textures are often completely obliterated. SR-type ignimbrites are commonly highly rheomorphic, exhibiting lineation, foliation and numerous styles of folding (Branney et al. 2004; Andrews and Branney 2011). Folding occurs on a variety of scales from microscopic to metre-scale. Where rheomorphic, the ignimbrites may generate an upper autobreccia, and in cases where rheomorphic flow continues beyond the limits of original pyroclastic deposition, a basal autobreccia is generated. Such autobrecciation is common in silicic lavas, and rheomorphic ignimbrites are commonly 'lava-like' in hand specimen; in such cases, especially with limited outcrop to reveal changes in unit thickness with topography, unambiguous classification of eruptive style may not be possible (c.f. Henry and Wolff 1992).

The scarce non-welded ignimbrites allow the granulometric character of the deposits, inferred from the welded ignimbrites, to be quantified. SR-type ignimbrites are better sorted than the majority of ignimbrites from other rhyolitic provinces (Fig. 2c) and are dominated by coarse ash-grade bubble-wall glass shards. A secondary component of the ignimbrites is the abundant, angular to sub-angular clasts of dense, black volcanic glass (e.g. Branney et al. 2008; Ellis and Branney 2010; Fig. 2d), which are commonly less than a few centimetres in diameter. These dense glass clasts are inferred to represent hyaloclastite formed as a result of effusion of rhyolitic materials into standing water (Ellis and Branney 2010). Clasts of other lithologies are rare to absent in SR-type ignimbrites.

Although fallout associated with the volcanism in the CSRP is dispersed across much of North America from central Washington to Nevada to Nebraska (Perkins and Nash 2002; Rose et al. 2003; Nash and Perkins 2012), it is often poorly exposed beneath ignimbrite sheets in the CSRP itself, suggesting that distal ashfall may in part be of coignimbrite origin. SR-type fallout is composed of parallelbedded coarse ash to ash-grade material (Fig. 3a) with variable proportions of crystals and rarely small chips of angular dense, black glass. Framework-supported, well-sorted, parallel-bedded deposits of microvesicular pumice clasts typical of silicic volcanism elsewhere are rare throughout the province, although they have been reported from some locations (e.g. Deadeye Member, Ellis and Branney 2010; Grey's Landing Member, Andrews and Branney 2011).

Effusive silicic volcanism in the CSRP is dominated by extensive large-volume lavas (Fig. 3b), primarily located in 

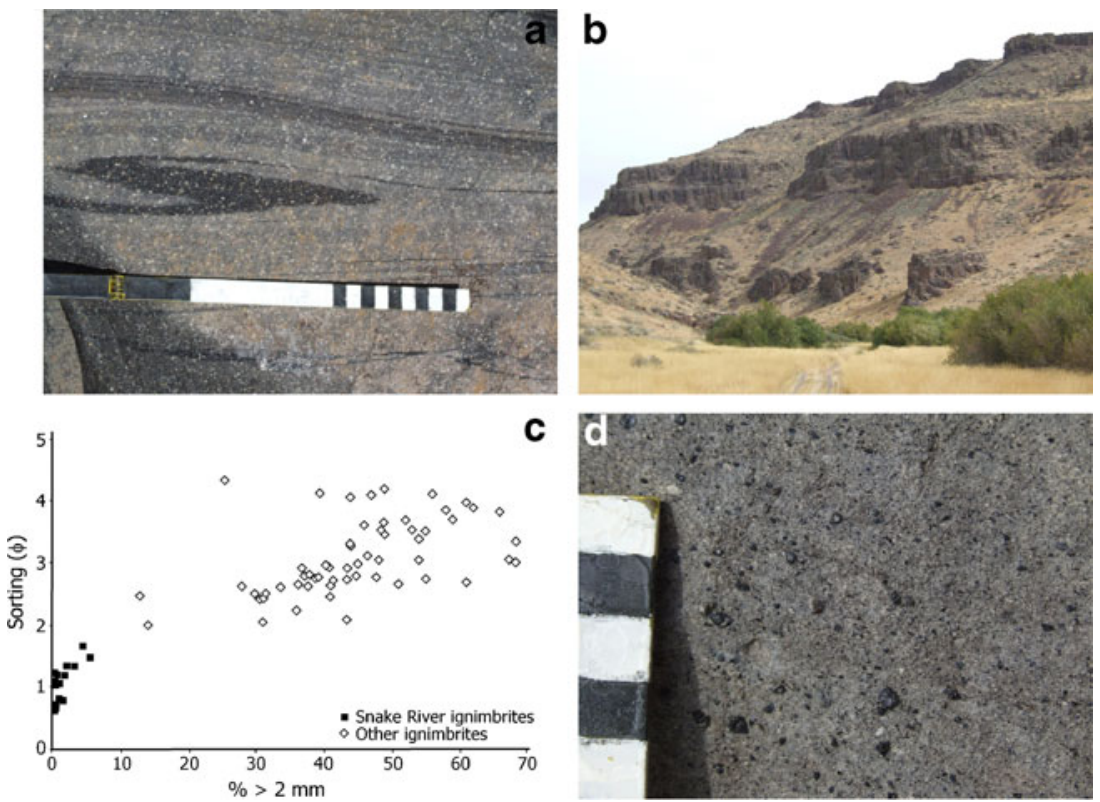

Fig. 2 Characteristics of SR-type ignimbrites. a Flow-folded, crystalrich, intensely welded Dive Creek ignimbrite from the West Bennett Mountains, small ruler gradations are $1 \mathrm{~cm}$. b Succession of welded ignimbrites in the East Bennett Mountains with cliff-forming welded tuffs separated by poorly exposed slope-forming units which may represent separate, non-welded facies of the same ignimbrites or

the Bruneau-Jarbidge region. Due to their size and extent, the lavas were long misinterpreted as welded ignimbrites and were only recognised as lavas after thorough investigations in the area (Bonnichsen 1982a). The largest SR-type rhyolitic lava known is the Sheep Creek lava, which is $>200 \mathrm{~km}^{3}$ in volume (Bonnichsen 1982b; Bonnichsen and Kauffman

separate units. c Grain size diagram illustrating the exceptionally high degree of sorting and lack of coarse material in SR-type ignimbrites (Branney et al. 2008). d Non-welded base of the Tuff of Wooden Shoe Butte in Trapper Creek containing abundant centimetre to subcentimetre-scale angular clasts of dense vitrophyre in a matrix of glass shards

1987), but a number of others have volumes between 10 and $100 \mathrm{~km}^{3}$. Effusive eruptions dominate the later stage of activity; in the case of the Bruneau-Jarbidge region, one rhyolitic lava is intercalated in the ignimbrite succession and at least eight others follow the cessation of explosive volcanism (Bonnichsen 1982b; Cathey and Nash 2009).

Fig. 3 Additional lithofacies associated with SR-type volcanism. a Parallel-bedded coarse ash fallout at the base of Cougar Point Tuff XI overlying a well-developed palaeosol, Jarbidge Canyon, NV, USA. b Autobreccia at the base of the Balanced Rock lava which reaches $20 \mathrm{~m}$ in thickness in places. c Accretionary lapillibearing phreatomagmatic ignimbrite, the Deadeye Member of Ellis and Branney (2010) in the Cassia Mountains. d Fluvial reworking of the tephra underlying the Wooden Shoe Butte ignimbrite, Trapper Creek, ID, USA
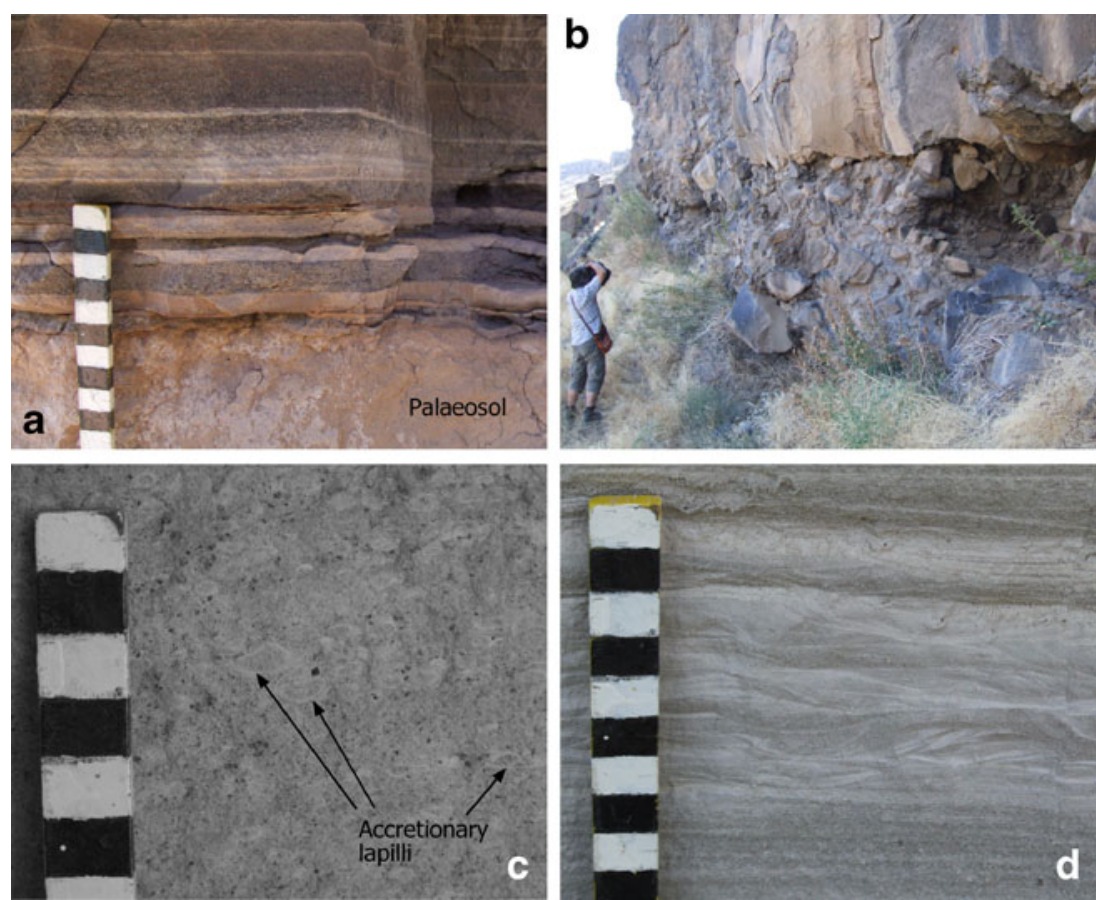
Further east, the Balanced Rock Lava and Shoshone Falls Rhyolite Lava are also amongst the youngest silicic rocks present in the Twin Falls area.

The interaction of water and magma is a common feature in the CSRP among both rhyolites and basalts. One rhyolitic hydrovolcanic unit, the Deadeye Member, has been described in detail (Ellis and Branney 2010); it is interpreted as a non-welded phreatomagmatic ignimbrite containing abundant accretionary lapilli (Fig. 3c) and dense glass clasts (yet no clasts of microcrystalline or 'devitrified' rhyolite). Numerous other rhyolitic units in the CSRP contain rimmed pellets or accretionary lapilli, and peperitic bases to units have been reported from both the northern and southern margins of the plain (Branney et al. 2008) in addition to abundant reworking of pyroclastic materials (Fig. 3d). Phreatomagmatic tuff rings and cones of basaltic composition are common (e.g. Godchaux et al. 1992; Brand and White 2007) in addition to abundant 'water-affected basalt' and pillow lavas which reflect their presence during the Miocene of Lake Idaho (Godchaux and Bonnichsen 2002). The timing and extent of Lake Idaho are known in the western Snake River Plain where it existed between $\sim 12$ and $1 \mathrm{Ma}$ (Jenks and Bonnichsen 1989) via the presence of pillow deltas, brecciation of rhyolitic lavas on flowing into water and the restriction of opal development to less than $800 \mathrm{~m}$ above sea level in rocks erupted $\sim 11.5 \mathrm{Ma}$. Lake Idaho is poorly constrained in the CSRP, nor is the effect (if any) of the lake on the eruptive style of the intensely welded ignimbrites well understood.

\section{Eruptive sources}

Rhyolitic rocks in the CSRP are found at the margins of the plain, with basalts covering the axis: as a result, the sources for the rhyolites are obscured. The region surrounding the Bruneau and Jarbidge rivers has been proposed as an "eruptive centre" for the voluminous Cougar Point Tuff succession which covers much of the surrounding area (Bonnichsen and Citron 1982). However, Bonnichsen (1982a) stated explicitly that the term was used to describe 'the geographic region from which were erupted the numerous volcanic units' rather than any resolvable caldera or group of vent structures. Subsequently, Pierce and Morgan (1992) used Bouger and gravity anomalies to propose the Twin Falls and Picabo eruptive centres along the axis of the CSRP. Following the model of the Yellowstone and Heise fields, it was inferred that explosive volcanism was sourced from the Bruneau-Jarbidge region for $\sim 2$ Ma prior to activity beginning in the Twin Falls eruptive centre. However, lithofacies exhibited by the ignimbrites throughout the CSRP are atypical of proximal regions. Mega-breccias, which characterise caldera collapse events in other silicic systems (e.g. Lipman 1976, 1997), have not been reported from the CSRP, and the thickest ignimbrites only reach $\sim 100 \mathrm{~m}$ rather than kilometre-scale as reported from intra-caldera settings (e.g. Sparks et al. 1985; Bachmann et al. 2002). Likewise, largescale caldera faults, dikes or other feeders for rhyolitic eruptions are not known in the CSRP. Although no calderas are exposed in the CSRP, their existence appears likely under the basaltic cover as explosive rhyolitic eruptions forming outflow ignimbrite sheets larger than $50 \mathrm{~km}^{3}$ without calderas are rare (e.g. Lavallée et al. 2006).

Following the explosive volcanism which produced the Cougar Point Tuff succession, numerous rhyolitic lavas of unusually large volume (up to $200 \mathrm{~km}^{3}$ ) were erupted in the Bruneau-Jarbidge region (Bonnichsen 1982b; Bonnichsen and Kauffman 1987). The lavas appear to be buttressed to the south by an arcuate structure, inferred by Bonnichsen (1982a) to be the southern margin of the Bruneau-Jarbidge eruptive centre. However, there appears to be little or no relationship between this arcuate structure and the underlying ignimbrites of the Cougar Point Tuff, suggesting that it developed between the end of explosive volcanism and the onset of effusive volcanism. The transition between explosive and effusive volcanism appears to characterise the CSRP as a whole, with the eruption of rhyolitic lavas commonly at the end of an explosive activity at any given location.

Alternatives to the paradigm of discrete eruptive centres have also been proposed, including the idea that the volcanism in the CSRP originated from one large single zone which has subsequently been distorted by the extension associated with the rifting of the western Snake River Plain (Godchaux and Bonnichsen 2002; Fig. 1). Branney et al. (2008) proposed that volcanism may have been sourced from a series of shingled, overlapping calderas within the CSRP which are gradually young to the north-east rather than the discrete loci of eruptive centres as commonly represented.

\section{Eruptive volumes and frequency}

The total amount of rhyolite erupted from the CSRP has been estimated by a variety of methods. By taking the thickness of the rhyolite in regions surrounding the CSRP and including the area covered by basalt in the centre of the plain, Bonnichsen et al. (2008) estimated the total volume of rhyolite erupted as $\sim 10,000 \mathrm{~km}^{3}$. Leeman et al. (2008) estimated between 7,000 and $30,000 \mathrm{~km}^{3}$, and Boroughs et al. (2012a) estimated between 10,000 and $30,000 \mathrm{~km}^{3}$. By using the distribution of airfall material, Perkins and Nash (2002) estimated that the volume of the CSRP was $\sim 10,000 \mathrm{~km}^{3}$. Attempts have been made to apportion this volume between the lavas and ignimbrites, with Leeman et al. (2008) estimating that the lavas in the Bruneau-Jarbidge region comprise $15 \%$ of the $10,000 \mathrm{~km}^{3}$ estimated by Perkins and Nash (2002). While this proportion may be appropriate for the Bruneau-Jarbidge region, for the CSRP as a whole, it is unlikely that effusive eruptions contribute much more than 
$\sim 10 \%$ of the total volume of rhyolite. These estimates, while different, are consistent in that they converge on approximately $10,000-30,000 \mathrm{~km}^{3}$.

Apportioning the estimated total volume into individual events via correlating units between exposed sections allows the frequency of eruption and the volume of each eruption to be estimated. The eruptive frequency is the easier to constrain as numerous fault scarps and canyons contain vertically stacked successions of ignimbrites. The best-known such succession is that of the Cougar Point Tuff which contains ten ignimbrites (Cathey and Nash 2004), erupted between $\sim 12.8$ and $\sim 10.5 \mathrm{Ma}$, giving an eruptive frequency of 4.3 eruptions per million years as constrained by ${ }^{40} \mathrm{Ar} /{ }^{39} \mathrm{Ar}$ geochronology. This represents a minimum frequency of eruption as other CSRP successions may record ignimbrites erupted within this time frame but not correlative with the Cougar Point Tuff succession. To make an estimate of the maximum frequency of eruption, multiple regions to both the north and south of the plain must be considered. Bonnichsen et al. (2008) developed a province-scale stratigraphy termed composition and time (CAT) groups using whole rock compositions, magnetic polarity, available geochronology and relative stratigraphic position within a section. The CAT group system places 85 rhyolitic units of the CSRP (both lavas and ignimbrites) into groups of relative similarity. A typical CAT group contains numerous rhyolitic units which in some cases cannot be correlatives (i.e. they may be documented as a lava and an ignimbrite or stratigraphically distinct at the same location) or in other cases may be the product of a single eruption (see the following discussion). Following recent correlations, within the CAT group system, there are 38 ignimbrites which were erupted between 13 and $10 \mathrm{Ma}$, which gives a maximum eruptive frequency of 12.6 eruptions per million years if no further units correlated.

Alternatively, eruptive frequency may be estimated from the airfall record, which is partially preserved in numerous basins in the western USA (e.g. Perkins et al. 1995; 1998; Perkins and
Nash 2002; Anders et al. 2009). The composite record of Perkins and Nash (2002) provides an eruptive frequency of $\sim 12$ explosive eruptions per million years for the period encompassing the Cougar Point Tuff succession and $\sim 14$ explosive eruptions per million years for the period between 12.7 and 8.5 Ma. However, this record suffers from the same problems of correlation as the ignimbrite record as Perkins and Nash (2002) point out; the record may be an overestimate of eruptive frequency. Thus, the frequency of largescale explosive eruptions from the CSRP may be bracketed as between 4 and 15 per million years. By contrast, using the ignimbrite record, the frequency of explosive eruption (number of ignimbrites/total length of volcanism) from the younger Heise and Yellowstone centres is 2.3 and 2.4/Ma, respectively (Christiansen 2001; Morgan and McIntosh 2005).

Constraining the products of individual eruptions by correlating ignimbrites between exposed sections is challenging. The similarity in field appearance, mineralogy and the lack of well-exposed fallout stratigraphies at the bases of units renders traditional field methods of little use. Rather, recent efforts have shown that combining numerous lines of geochemical evidence can be successful in correlating ignimbrites (Ellis et al. 2012a). The largest ignimbrites so far recorded from the CSRP are Cougar Point Tuff XIII $\left(\sim 1,000 \mathrm{~km}^{3}\right)$ and Cougar Point Tuff XI and the Steer Basin Tuff (both $\sim 350 \mathrm{~km}^{3}$ ), although these values are likely to be underestimates.

\section{Geochemical characteristics}

\section{Whole rock compositions}

Silicic rocks of the CSRP are almost all rhyolites with whole rock $\mathrm{SiO}_{2}$ (anhydrous) ranging between 69 and 77 wt.\% (Bonnichsen et al. 2008; Fig. 4) and, compared to many other rhyolites, high levels of $\mathrm{FeO} *$ (typically $>2$ wt.\%) and high-
Fig. 4 Total alkali-silica plot illustrating the bimodality of bulk compositions in the CSRP with abundant rhyolite and basalt but no intermediate compositions, data from Bonnichsen et al. (2008)

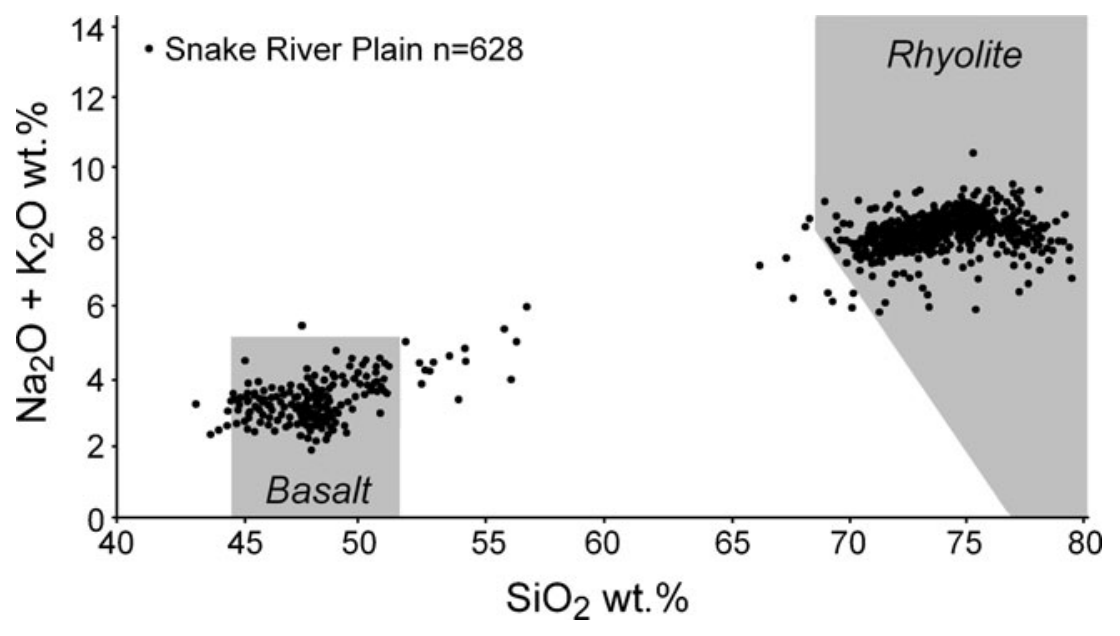


field-strength elements such as $\mathrm{Zr}$ and $\mathrm{Nb}$ (Cathey and Nash 2004; Christiansen and McCurry 2008). Cumulatively, these features indicate that the CSRP rhyolites have affinities with A-type granites.

Bulk silicate earth-normalised trace element diagrams illustrate depletions in $\mathrm{Ba}, \mathrm{Sr}, \mathrm{P}$ and $\mathrm{Ti}$ consistent with fractionation of sanidine, plagioclase, apatite and Fe-Ti oxides, as observed in the mineral assemblage (Fig. 5). Rare earth element (REE) patterns are almost identical for rhyolites throughout the CSRP, with the main variations being the magnitude of the Eu depletion. No CSRP rhyolites exhibit the light REE depletion often produced in 'common' rhyolites by fractionation of allanite, chevkinite or monazite, nor have these phases been identified in any CSRP rhyolite (see the following discussion). Heavy REE do however exhibit a greater dispersion in normalised abundance than light REE (Fig. 5), but there is no correlation between $\mathrm{La} / \mathrm{Lu}$ and indices of fractionation such as $\mathrm{Eu} / \mathrm{Eu}^{*}$. Probably, the slight variability in $\mathrm{La} / \mathrm{Lu}$ among the rhyolites is inherited from the source region.

Bonnichsen et al. (2008) show that most CSRP rhyolites are, to a first approximation and making allowance for fractional crystallisation, uniformly enriched in incompatible trace elements compared to that of average continental crust (as estimated by Taylor and McLennan (1985)), implying that the latter composition is a plausible source for the rhyolites. The extent of incompatible element enrichment indicates $10-25 \%$ melting of such a source to produce the rhyolites. Large-scale involvement of continental crust in CSRP rhyolite genesis is consistent with isotopic evidence (see the following discussion).

A very noteworthy feature of CSRP ignimbrites is their apparent lack of internal compositional zoning. Distinct vertical profiles in major and, especially, both compatible and incompatible trace element concentrations have long been regarded as the 'norm' for medium- to large-volume silicic ignimbrites with low to moderate crystal contents (Smith 1979; Hildreth 1981); the iconic example is the Bishop Tuff of California, in which the first-erupted, highly evolved rhyolitic tephra is overlain by successively less differentiated material emplaced as the eruption tapped deeper into a vertically zoned magma chamber (Hildreth 1979; Hildreth and Wilson 2007). In Fig. 6, the concentrations of Ti (a compatible element), $\mathrm{Rb}$ (an incompatible element) and $\mathrm{SiO}_{2}$ in basal and upper vitrophyres of 25 CSRP ignimbrites are plotted. Only one exhibits a significant base-top contrast, and that particular example is reversely zoned (i.e. more evolved compositions at the top of the sheet). There is a similar lack of base-top contrast in mineral compositions (Fig. 7c), suggesting that the apparent homogeneity is a primary feature and not the result of rheomorphic mixing; in any case, field evidence indicates that the large-scale internal stratigraphy of these tuffs is not overturned or destroyed during rheomorphism (Andrews and Branney 2011). Lack of compositional zoning in CSRP ignimbrites awaits explanation.

\section{Mineral compositions}

Rhyolites of the CSRP are generally crystal-poor with crystal contents of between 2 and $25 \%$ and most commonly around $10 \%$. They are characterised by an anhydrous mineral assemblage consisting of plagioclase $\left(\mathrm{An}_{25-50}\right) \pm$ sanidine \pm quartz + augite \pm pigeonite \pm orthopyroxene \pm fayalitic olivine \pm ilmenite \pm magnetite + accessory zircon and apatite (Fig. 7). Hydrous phases such as biotite and amphibole are conspicuously absent throughout the CSRP. Notably, all crystal phases are internally compositionally near-homogeneous with coreto rim-zonation being slight to absent. Sieve-textured plagioclase, melt inclusions and broken crystals are common. Within the crystal cargo, clots of pigeonite, augite, plagioclase, Fe-Ti oxides, zircon and apatite of varying morphology are found in almost every CSRP rhyolitic unit, and these crystal aggregates appear to be a major repository of zircon (e.g. Cathey and Nash 2009; Ellis and Wolff 2012).

Multiple compositional modes of both pigeonite and augite are common in the CSRP (e.g. Cathey and Nash 2004; Andrews et al. 2008; Ellis et al. 2010) and are suggestive of complex conditions of magma storage in the crust prior to eruption. Interestingly, after studying both the ignimbrites

Fig. 5 Bulk silicate earth (BSE; McDonough and Sun 1995) normalised diagrams for CSRP rhyolite. a Trace elements and b rare earth elements
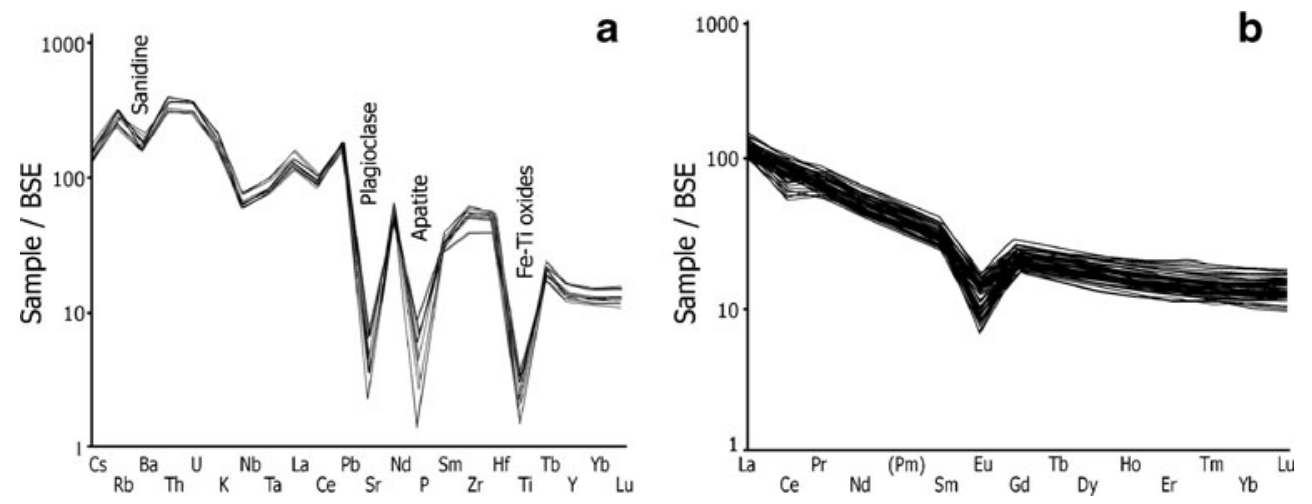

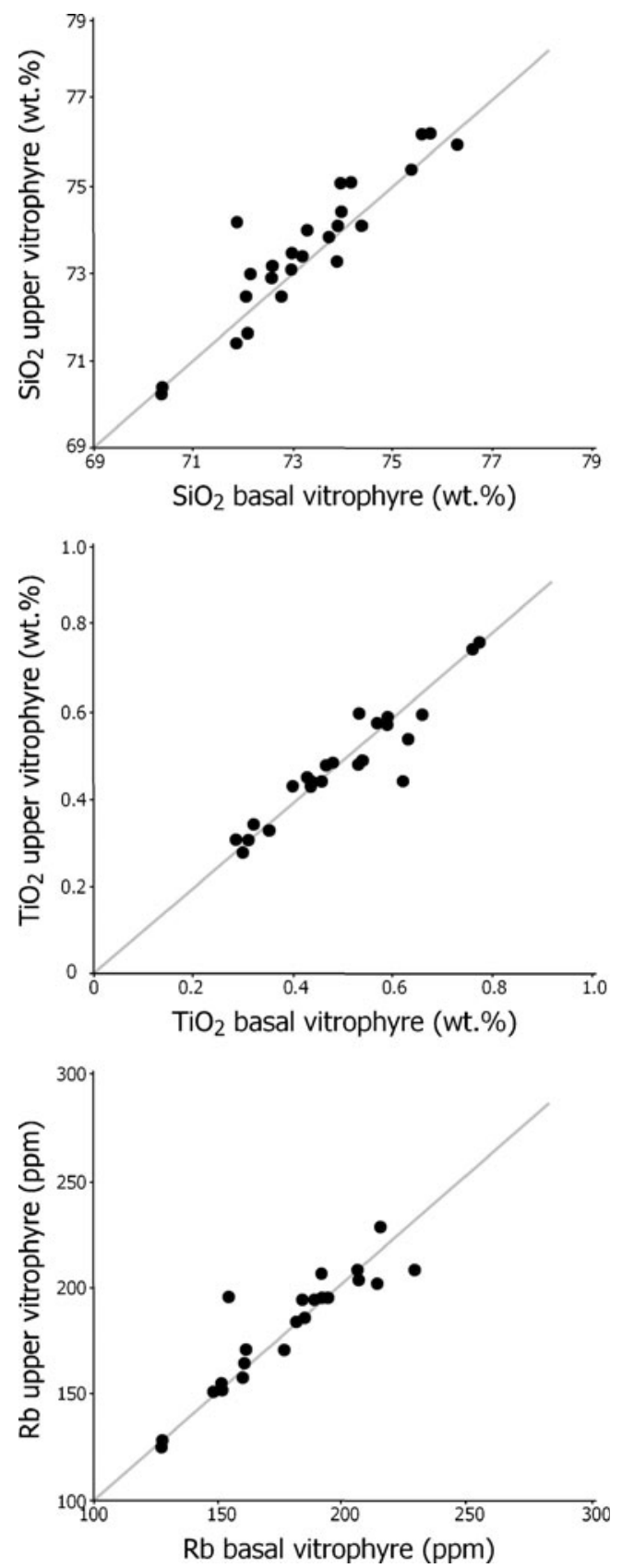

Fig. 6 Compositional homogeneity of ignimbrite sheets in the CSRP illustrated by the good correlation between compositions of basal and upper parts of an individual sheet. Each data point represents a single ignimbrite and grey lines represent 1:1 correlation. Data from Bonnichsen et al. (2008) and Ellis et al. (2010) and unpublished data

and the lavas of the Bruneau-Jarbidge region, Cathey and Nash (2009) found that heterogeneity in pyroxene compositions was restricted to the ignimbrites, an observation which appears to hold for the whole CSRP. Indeed we do not know of any lava in the CSRP which contains multiple compositions of pigeonite and augite.

Occasional zircon grains from the ignimbrites and lavas of the Bruneau-Jarbidge eruptive centre have U-Pb core ages which indicate minor antecrystic inheritance from earlier eruptive episodes in the Snake River Plain and, rarely, from the Idaho Batholith (Cathey et al. 2008; Hill and Schmitz 2011).

Mineral thermometers (two feldspar, two pyroxene, two oxide) indicate that the CSRP rhyolitic magmas were hot $\left(\geq 850{ }^{\circ} \mathrm{C}\right.$; Honjo et al. 1992; Cathey and Nash 2004; Andrews et al. 2008; Cathey and Nash 2009; Ellis et al. 2010; Fig. 8), and similar results have been reported using zirconium saturation thermometry (e.g. Perkins et al. 1995; Nash et al. 2006). Ti-in-quartz and Ti-in-zircon thermometry, respectively, has also produced estimates of magmatic temperatures which are similar to mineral pair thermometry (e.g. Cathey et al. 2008; Cathey and Nash 2009). The high magmatic temperatures occur throughout the history of the CSRP for at least $6 \mathrm{Ma}$, reflecting persistence of the thermal input into the crust. Younger rhyolites of the hotspot track at the Yellowstone and Heise centres have magmatic temperatures lower than the CSRP rhyolites (Bindeman et al. 2008; Watts et al. 2011), transitional to those of 'typical' rhyolites. No systematic variation in magma temperatures has been found to be associated with eruptive style, with lavas showing the same range in magmatic temperatures as magmas which erupted explosively. The high temperatures as reported from mineral thermometry are associated with reducing conditions, typically QFM $\pm 0.5 \log$ units (Cathey and Nash 2004; Christiansen and McCurry 2008). Such hot reducing conditions have reproduced SRP-type compositions in recent experimental work, further supporting the inferences of geothermometry (Almeev et al. 2012). The high magmatic temperatures support the observation that CSRP melts were not saturated with REE-rich trace phases.

\section{Glass compositions}

Despite bulk compositions reaching as low as 69 wt.\% $\mathrm{SiO}_{2}$, Snake River Plain glasses are almost exclusively high-silica rhyolite (Perkins et al. 1995; 1998; Perkins and Nash 2002; Nash and Perkins 2012). Thick successions of non-welded material containing both reworked and primary pyroclastic material are preserved in a number of basins to the south of the plain (e.g. Trapper Creek, Goose Creek, Big Cottonwood Canyon). Studies of individual shards present within these fallout successions have illustrated that multiple compositional populations of glass may be present within a single bed (Perkins et al. 1995; 1998). By combining the chemical composition of glass present in a deposit with ${ }^{40} \mathrm{Ar} /{ }^{39} \mathrm{Ar}$ geochronology, individual tephras sourced from the Snake River Plain have been traced as far as southern Nevada (Perkins and Nash 2002). The presence of multiple glass compositions within the fallout succession is consistent with the presence of multiple compositions of both augite and pigeonite in the ignimbrites of the CSRP. 
Fig. 7 Mineral compositions from CSRP rhyolites. a Compositions of pyroxenes and olivines from the CSRP, with data from 33 rhyolitic units taken from Cathey and Nash (2004) and Ellis et al. (2010) and unpublished data. Augite and pigeonite are the common ferromagnesian phases in CSRP rhyolites, with orthopyroxene and fayalitic olivine only present in a handful of cases. b Feldspar compositions from $31 \mathrm{CSRP}$ rhyolites with data from Cathey and Nash (2004), Andrews et al. (2008) and Ellis et al. (2010) and unpublished data. c Compositions of pyroxenes from basal and upper vitrophyres of CSRP ignimbrites illustrating the compositional homogeneity of minerals throughout a unit
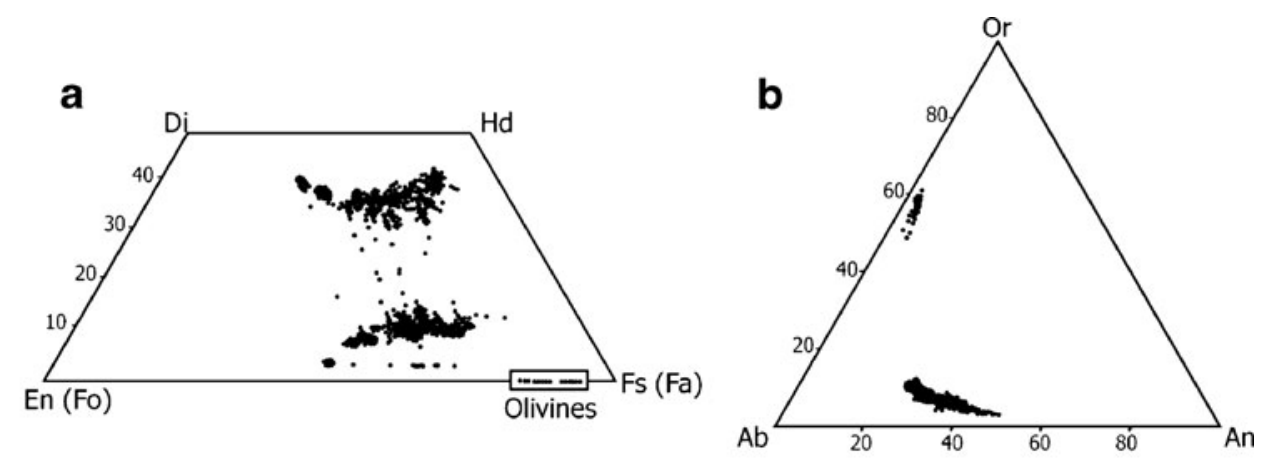

\section{Isotopic constraints on petrogenesis}

The rhyolites of the CSRP represent a young igneous province emplaced on an old craton with a number of isotopically disparate reservoirs available for participation in petrogenesis (Armstrong et al. 1977; Fleck and Criss 1985; Leeman et al.

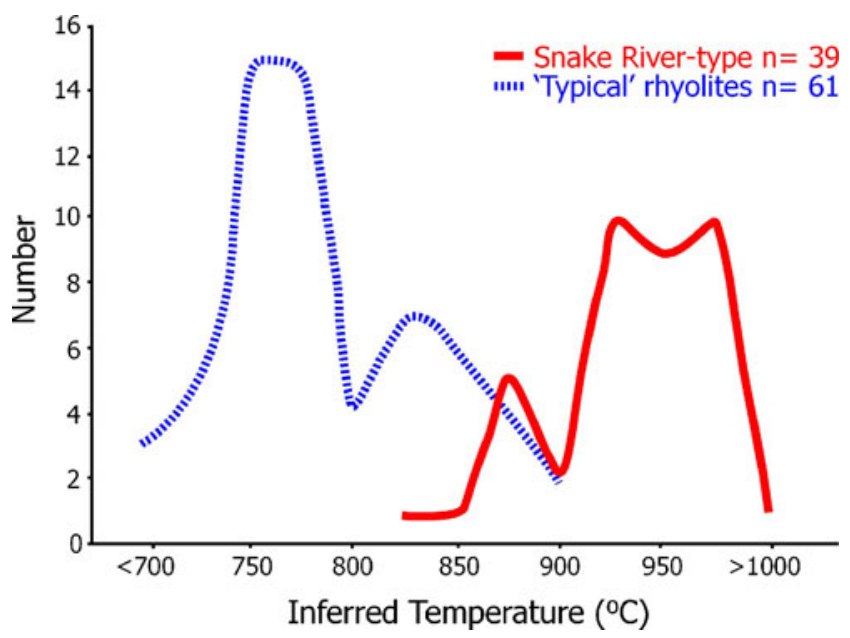

Fig. 8 Illustration of the higher magmatic temperatures of rhyolites in the CSRP compared to rhyolites from other provinces (e.g. Knesel et al. 1999; Wilson et al. 2006; Hildreth and Wilson 2007) as inferred by multiple mineral thermometers. Where any single rhyolite had temperatures derived by different thermometers, the average temperature was used to generate the curves
1985; Nash et al. 2006). The transition from older continental crust to younger accreted terrains is abrupt at the Western Idaho Suture Zone of Fleck and Criss (2004), though the boundary becomes more diffuse to the south. Continuing east from the cratonic boundary, the continental crust is heterogeneous and heavily modified by Cretaceous magmatism that produced the Idaho batholith and subsequent Eocene magmatism that intruded through the Cretaceous batholith rocks with accompanying large-scale hydrothermal alteration. Finally, during the mid-late Miocene, the injection of basalts into the lower and middle crust, and the formation of a large lens of gabbroic sills prior to and contemporaneous with CSRP-OH silicic volcanism, has further modified this variable lithosphere (Bonnichsen et al. 2008; McCurry and Rodgers 2009; Rodgers and McCurry 2009). The variability in possible assimilants has made assessing the mantle contribution to CSRP rhyolites a subject of contention. On the basis of radiogenic and stable isotope data, all workers have agreed that the CSRP rhyolites contain a proportion of melted crust, but estimates of the proportion range from $10 \%$ (Nash et al. 2006) to almost $100 \%$ (Boroughs et al. 2005).

\section{Radiogenic isotopes}

Neodymium concentrations vary less than those of either $\mathrm{Sr}$ or $\mathrm{Pb}$ among major crustal and mantle reservoirs and therefore more reliably indicate relative contributions to magma from 
different sources (Perry et al. 1993). Published values of ${ }^{143} \mathrm{Nd} /{ }^{144} \mathrm{Nd}$ for the CSRP rhyolites range from approximately $0.5124(\varepsilon \mathrm{Nd}=-4.6)$ to $0.5120(\varepsilon \mathrm{Nd}=-12.4)$ and average $\sim 0.5122(\varepsilon \mathrm{Nd}=-8.5)$, with a relatively narrow distribution around the mean (Wright et al. 2002; Nash et al. 2006; McCurry and Rodgers 2009; Fig. 9); these are, broadly speaking, 'crustal' ratios. Initial ${ }^{87} \mathrm{Sr} /{ }^{86} \mathrm{Sr}$ ratios range from 0.70865 for Cougar Point Tuff III (Bonnichsen et al. 2008) to 0.71347 for one of the McMullen Creek members (Wright et al. 2002), consistent (but poorly coupled) with the values and range in ${ }^{143} \mathrm{Nd} /{ }^{144} \mathrm{Nd}$ (Fig. 9). Other rocks exposed in proximity to the CSRP (e.g. crustal xenoliths, Idaho batholith granitoids, Eocene granitoids, Eocene volcanics, Columbia River basalts and SRP basalts) have $\mathrm{Sr}$ and $\mathrm{Nd}$ ratios that span practically the entire range of global values. The availability of such a wide spectrum of potential source rocks $\left({ }^{87} \mathrm{Sr} /{ }^{86} \mathrm{Sr}=0.70235-\right.$ 0.82979, $\varepsilon \mathrm{Nd}=+10$ to -52 ; Leeman et al. 1985 and earlier references) places few limits on petrogenesis unless source materials can be delineated on the bases of additional criteria. To further complicate matters, the isotopic composition of the lower and middle crust is poorly constrained by a handful of xenoliths from a few lavas of the eastern Snake River Plain (Leeman et al. 1985; Watts et al. 2010) and therefore may not be representative of the crustal composition beneath the CSRP. A further challenge for isotopic modelling comes from the basalts found in proximity to the CSRP. Snake River Plain basalts that overlie, and are typically several million years younger than, the rhyolites have much lower ${ }^{143} \mathrm{Nd} /{ }^{144} \mathrm{Nd}$ ratios and higher ${ }^{87} \mathrm{Sr} /{ }^{86} \mathrm{Sr}$ ratios than basalts in the early stages of hotspot volcanism (i.e. Columbia River and Steens basalts). The required mantle contribution to the rhyolites is low if the early flood basalts are considered to represent the mantle component and higher if the younger SRP basalts are used (Boroughs et al. 2012b); however, most workers favour the latter hypothesis (Wright et al. 2002; Nash et al. 2006; McCurry and Rodgers 2009).

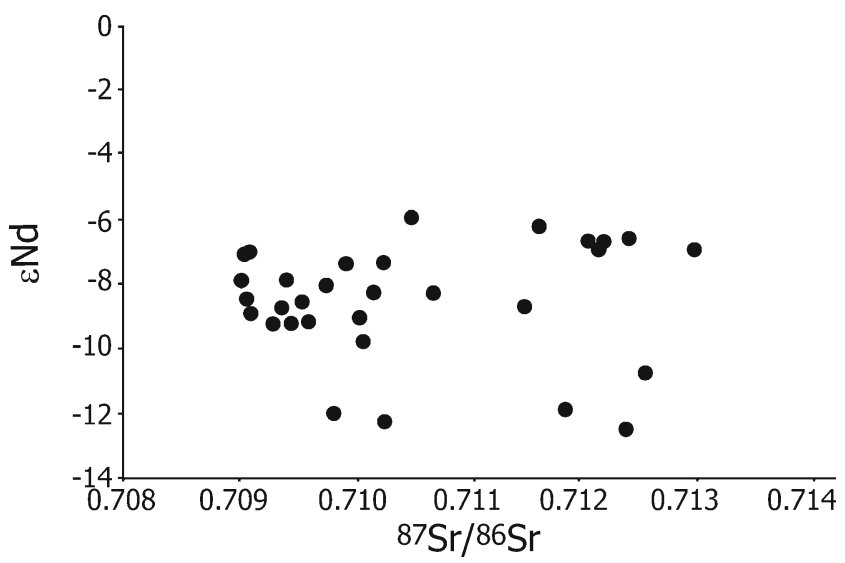

Fig. $9 \mathrm{Sr}$ and $\mathrm{Nd}$ isotopic compositions of CSRP rhyolites with data from Wright et al. (2002), Nash et al. (2006), Bonnichsen et al. (2008) and Boroughs et al. (2012b) and unpublished data
To date, petrogenetic models using only $\mathrm{Nd}$ isotopes consistently indicate that both mantle and crustal material is necessary in the production of CSRP rhyolites (Wright et al. 2002; Nash et al. 2006; Bonnichsen et al. 2008; McCurry and Rodgers 2009; Boroughs et al. 2012b). Based on differing model constraints, mantle contributions of 10-60\% (Nash et al. 2006) to $80 \%$ (Wright et al. 2002) have been proposed. It is also clear that any contribution from the known Archean crustal rocks must be limited due to the strong leverage provided by their extremely low ${ }^{143} \mathrm{Nd} /{ }^{144} \mathrm{Nd}$ ratios (Leeman et al. 1985; Nash et al. 2006). It is worth noting that the wide ranges of potential mantle contributions indicated by Nash et al. (2006) serve to highlight the permissive nature of isotopic mixing models in the Snake River Plain. Regardless of these uncertainties, the overall slight increase in ${ }^{143} \mathrm{Nd} /{ }^{144} \mathrm{Nd}$ with time among CSRP rhyolites (Fig. 10) indicates that the regional crust became increasingly hybridised through time as mantle material replaced crustal material through anatexis and assimilation, in common with many other Cenozoic silicic volcanic fields and centres in the western USA (Perry et al. 1993).

The rhyolites exhibit a relatively narrow range of $\mathrm{Pb}$ isotopic compositions (Wright et al. 2002; Boroughs et al. 2012b; Fig. 11) which overlap with both SRP basalts and the Idaho batholith (Fig. 11) but have a much narrower compositional range than the Archean xenoliths as reported by Leeman et al. (1985). Lead isotopes are therefore permissive of mixing between mantle and crustal source materials to form the rhyolites, including Imnaha and Steens source mantle (Boroughs et al. 2012b), but place few additional constraints on petrogenesis.

Despite the large variations observed in bulk ${ }^{87} \mathrm{Sr} /{ }^{86} \mathrm{Sr}$ ratios (corrected to $11 \mathrm{Ma}$ ) within regional rocks and the consensus that both crustal and mantle have contributed to CSRP rhyolites, Sr isotopic variation with the crystal cargo of any single unit appears very limited (Wolff et al. 2011; Fig. 12). Determinations of ${ }^{87} \mathrm{Sr} /{ }^{86} \mathrm{Sr}$ via in situ laser ablation inductively coupled plasma mass spectrometry (LA-ICPMS) on plagioclase phenocrysts illustrate that little isotopic variability is found within a single CSRP rhyolite within a single crystal or from crystal to crystal. Moreover, the individual plagioclase grains in the rhyolites show only slight deviation from the bulk ${ }^{87} \mathrm{Sr} /{ }^{86} \mathrm{Sr}$ ratios of the ignimbrite. This result is different from that reported from the vast majority of igneous rocks, especially those emplaced onto ancient continental crust (Davidson et al. (2007) and references therein). Interestingly, two basalts intercalated within the rhyolitic succession on the northern margin of the CSRP exhibit significantly more variability than the surrounding rhyolites both between grains and within a single plagioclase (Wolff et al. 2011). This is a similar finding to that reported for the Columbia River basalts (Ramos et al. 2005), suggesting that the Snake River basalts are also the products of late-stage assembly of numerous isotopically diverse magmas. 
Fig. $10 \varepsilon N d$ composition of CSRP rhyolites showing a trend to less negative $\varepsilon \mathrm{Nd}$ over time, with data from Wright et al. (2002), Nash et al. (2006), Bonnichsen et al. (2008) and Boroughs et al. (2012b)

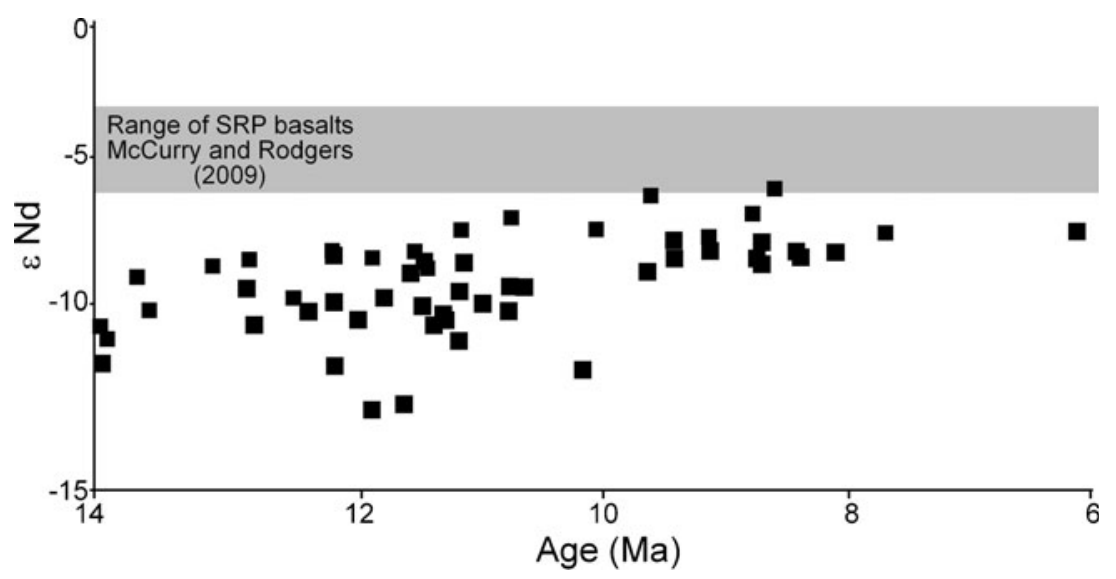

The apparently unique Sr isotopic homogeneity exhibited by the CSRP rhyolites has been attributed to the effect of temperature controlling the physical properties of the magma (Wolff et al. 2011). Although the CSRP magmas are significantly hotter than most silicic magmas, their low water contents $(<3.5$ wt.\% - Wolff et al. (2011) or even lower at 1.5-0.6 wt.\%-Almeev et al. (2012)) act to increase viscosity to be comparable to 'typical' rhyolites. The still relatively high viscosity (estimated at $\sim 5-6 \log$ Pa s using the model of Giordano et al. (2008)) acts to retard crystal-melt separation, so foreign crystals are not easily entrained. Indeed this is unlikely to happen on timescales shorter than that required for diffusive re-equilibriation. The high temperatures cause rapid diffusive equilibrium within crystals, orders of magnitude faster than seen in 'typical rhyolites' (Wolff et al. 2011). So, this combination of melt-crystal coupling and high speeds of diffusive equilibrium caused by high temperatures promotes isotopic homogeneity (Wolff et al. 2011).

\section{Oxygen isotopes}

Oxygen isotope compositions in the CSRP are one of the most remarkable characteristics of the province. Unlike any other silicic province known (including the younger part of the hotspot track), the rhyolites of the CSRP have ubiquitously low $-\delta^{18} \mathrm{O}$ values for all units so far sampled $(n=56)$.
Fig. $11 \mathrm{~Pb}$ isotopes of the CSRP rhyolites, basalts and surrounding crustal rocks, with data from Leeman et al. (1985), Wright et al. (2002), Gaschnig et al. (2011) and Boroughs et al. (2012b)
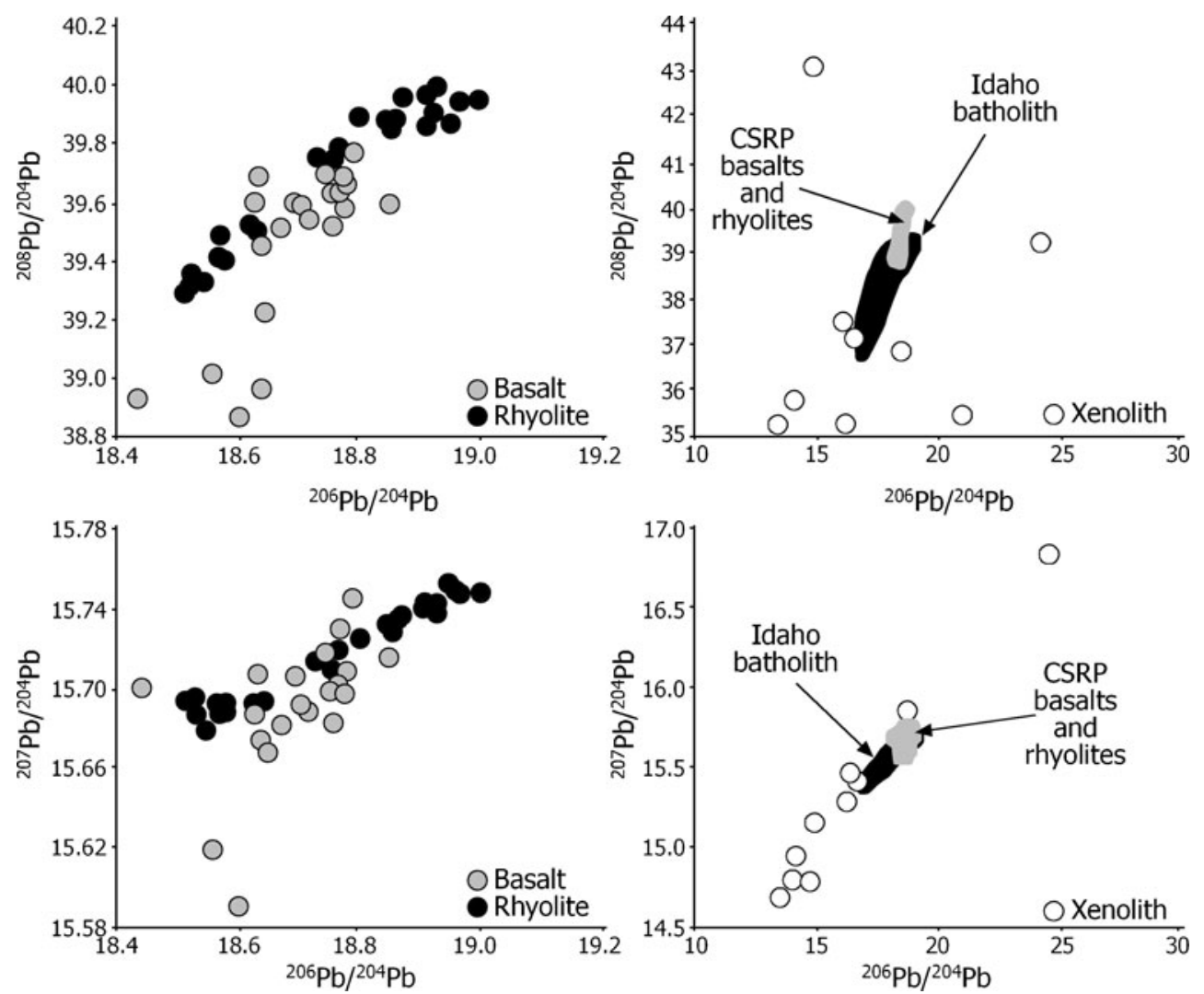

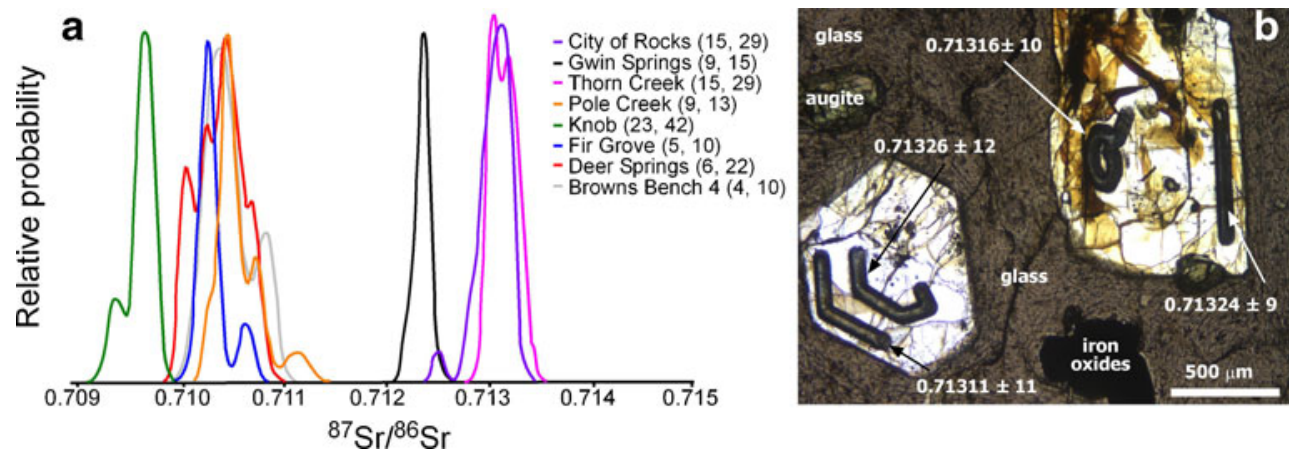

Fig. 12 a Relative probability plot for ${ }^{87} \mathrm{Sr} /{ }^{86} \mathrm{Sr}$ as determined via LAICPMS for CSRP rhyolites (after Wolff et al. (2011)). Note not only the restricted compositional range of a single unit but also the wide variability between units. Units represented here are ignimbrites from the

This dataset contains rhyolites spanning $\sim 200 \mathrm{~km}$ (E-W along the axis of the CSRP) and $\sim 8 \mathrm{Ma}$ and contains both lavas and ignimbrite, with all analyses having $\delta^{18} \mathrm{O}$ values between -1.2 and $4.8 \%$ (Boroughs et al. 2005; 2012a). This review focuses on rhyolites of the CSRP, but due to their similarity in physical character, chemistry and low- $\delta^{18} \mathrm{O}$ signature, units from further west along the hotspot track in the Owyhee Plateau and Juniper Mountain regions will be included in the discussion of oxygen isotopes (Fig. 13).
East Bennett Mountains (Fig. 1) and represent $\sim 2$ Myr of volcanism in the CSRP. b Example of plagioclase sampled via LA-ICPMS by Wolff et al. (2011) from the City of Rocks ignimbrite, East Bennett Mountains

Bulk laser fluorination mineral analyses of feldspar and quartz from CSRP rhyolites returned values well below $\sim 6 \%$, which is considered to be the lower limit of values produced by normal magmatic fractionation (Taylor 1968). Where possible, quartz-feldspar fractionations were determined by Boroughs et al. $(2005$; 2012a) and found to be consistent with fractionation at magmatic temperatures (Fig. 14) precluding postemplacement alteration, consistent with the fresh appearance and bulk geochemistry of the samples.

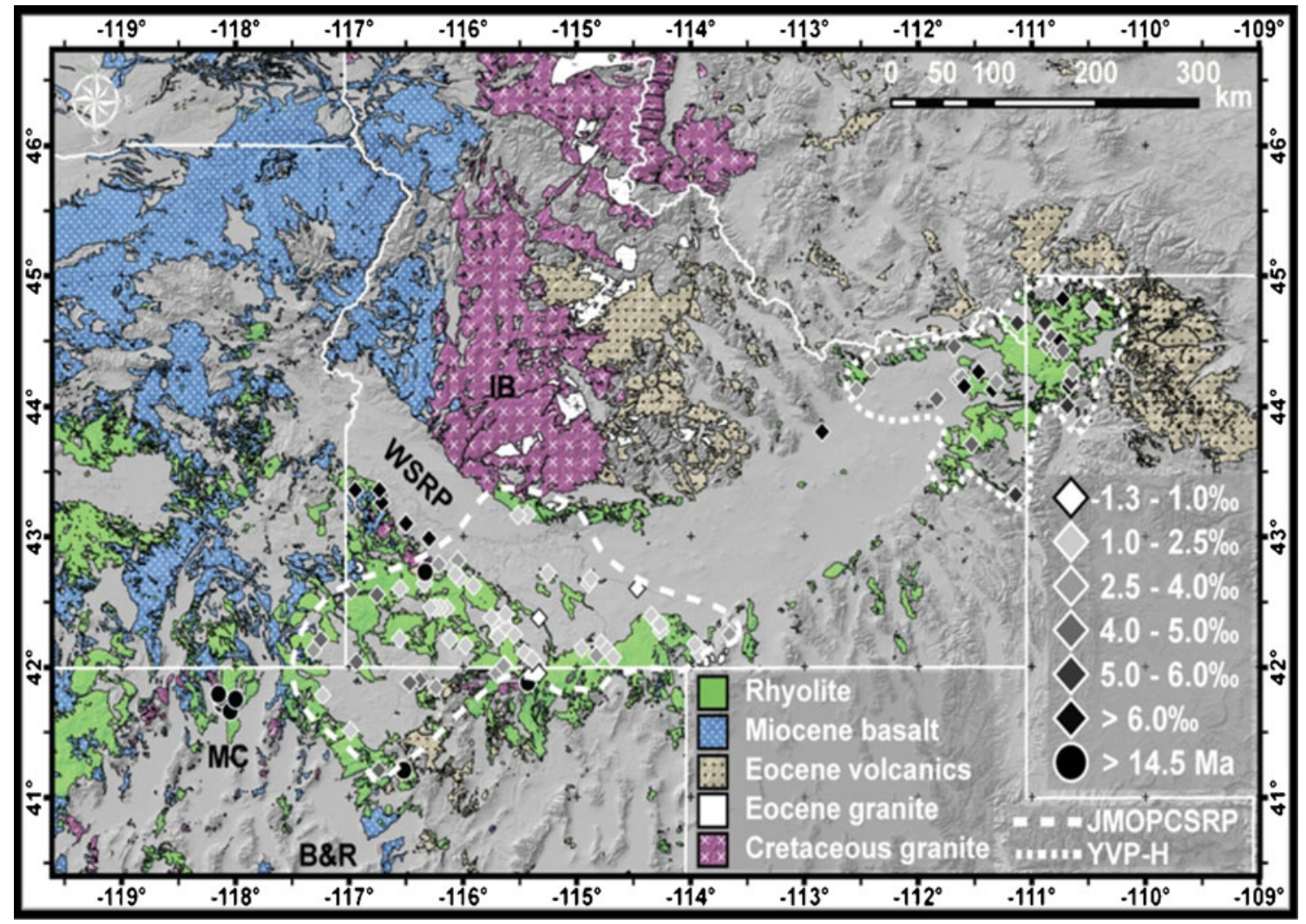

Fig. 13 Location map illustrating the geographic extent of the low$\delta^{18} \mathrm{O}$ province in the CSRP with data from Boroughs et al. (2005, 2012a), Bonnichsen et al. (2008) and Ellis et al. (2010). Inset indicates the magmatic $\delta^{18} \mathrm{O}$ values of units sampled in this study. JMOPCSRP

Juniper Mountain, Owyhee Plateau, central Snake River Plain, YVPH Yellowstone volcanic plateau and Heise, $B \& R$ basin and range, $M C$ McDermitt caldera, $I B$ Idaho batholith 
Fig. 14 a Oxygen isotopic composition of co-existing quartz and feldspar from $>50$ rhyolitic units (both lavas and ignimbrites) in the CSRP. Grey lines represent the isotopic equilibrium between quartz and feldspar at magmatic temperatures. b Relative probability plot illustrates the difference between the entirely depleted CSRP and the variably depleted Yellowstone and Heise volcanic fields. Data from Bindeman and Valley (2001), Boroughs et al. (2005), Bindeman et al. (2007), Watts et al. (2011) and Boroughs t al. (2012a)
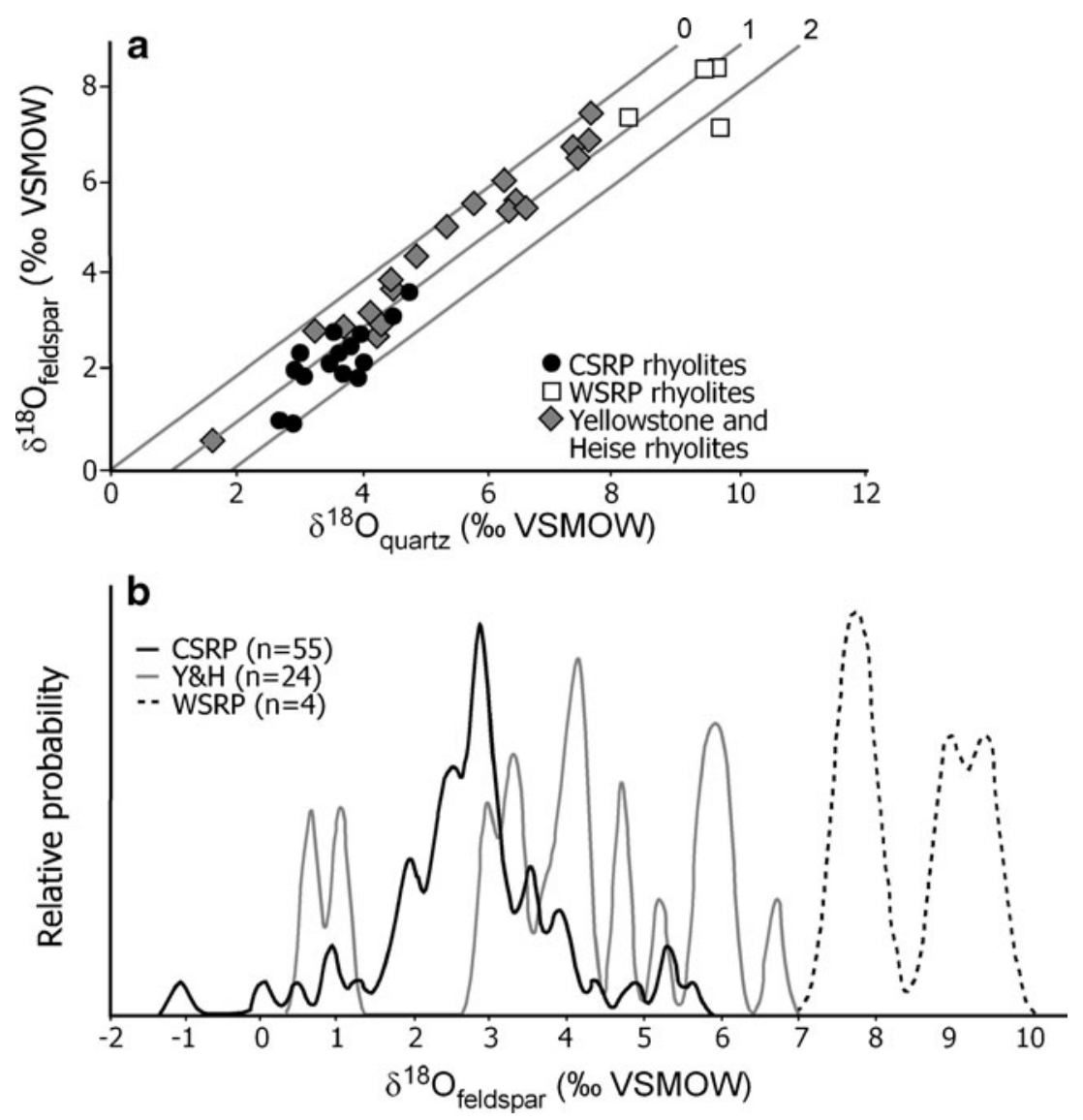

Oxygen isotope values show little correlation with eruptive style, temperature, major or trace elements or radiogenic isotopes (Boroughs et al. 2005; 2012a), but there is a gross correlation with location and, therefore, age across the CSRP (Figs. 13 and 14). The lowest observed values generally appear in the rhyolites near the centre of the province (e.g. BruneauJarbidge c. $\sim 10-12 \mathrm{Ma}$ ), while higher values (although still < $<6 \%$ ) are found at the eastern (younger) and western (older) margins (e.g. Albion Range and Juniper Mountain respectively). Also, the distribution of low $(<6 \%) \delta^{18} \mathrm{O}$ eruptives in the CSRP is distinctly bounded in both space and time. Samples of Jarbidge rhyolite lavas ( 15.5 Ma, Brueseke et al., submitted for publication) and lavas and ignimbrites from the McDermitt caldera ( 16.5 Ma, Henry et al. 2006$)$ that were collected from within the physiographic boundaries of the hotspot track all yield 'normal' $\delta^{18} \mathrm{O}$ values above $6 \%$. Contemporaneously erupted rhyolites $(\sim 10.5-11.5 \mathrm{Ma})$ in the Owyhee Front at the southwestern margin of the Western Snake River Plain also have normal- $\delta^{18} \mathrm{O}$ values despite their chemical and physical similarity to CSRP rhyolites (e.g. high temperature, anhydrous, "A-type"). The transition from low- $\delta^{18} \mathrm{O}$ volcanism to normal- $\delta^{18} \mathrm{O}$ volcanism in the lavas at the northwestern margin of the CSRP is extremely sharp and occurs between units of similar age over a distance of $\sim 20 \mathrm{~km}$.
Origin of low- $\delta^{18} \mathrm{O}$ rhyolites along the Yellowstone Hotspot track

Two models have been proposed for the origin of low- $\delta{ }^{18} \mathrm{O}$ rhyolites associated with the Yellowstone Hotspot, which may be broadly termed the 'crustal cannibalisation' model and the 'pre-existing source' model. Both models conclude that a component of hydrothermally altered crust is required in the source region but differ on the timing of alteration and nature of the altered material. Though the models are not mutually exclusive, neither one can uniquely explain the different characteristics of depletion observed in both the Yellowstone volcanic field and the central Snake River Plain.

\section{Crustal cannibalisation}

The crustal cannibalisation model (Bindeman and Valley 2001; Bindeman et al. 2007, 2008), was developed for the younger rhyolites of the Heise and Yellowstone systems ( $\leq$ $6 \mathrm{Ma})$ but has also recently been suggested for the CSRP (Watts et al. 2011). This model postulates that cyclical volcanism in active caldera settings produces hydrothermally altered crust in its early stages, which is subsequently melted to form low $-\delta^{18} \mathrm{O}$ rhyolite during later eruptive events. Initial 
magmatism produces normal- $\delta^{18} \mathrm{O}$ rhyolites, and proximal deposits of these rhyolites make up the caldera roof block for subsequent magmatic events. Younger volcanism then drives vigorous hydrothermal circulation, which alters the older rhyolites and drives their $\delta^{18} \mathrm{O}$ values down. These altered rhyolitic roof rocks are finally melted when large calderaforming eruptions drop them to suitable depths, and they are melted to form post-caldera collapse lavas and small volume tuffs. Although abundant data support this model for the Yellowstone and Heise systems (e.g. systematic normal and depleted $\delta^{18} \mathrm{O}$ volcanic cycles and inherited xenocrysts), its extension to the older rhyolites of the CSRP remains problematic for the following reasons:

1. No rhyolites younger than $14.5 \mathrm{Ma}$ with $\delta^{18} \mathrm{O}$ values above $4.8 \%$ have been found in the CSRP, Owyhee Plateau or Juniper Mountain regions. Vertical sections in several canyons expose continuous sequences, each representing at least $2 \mathrm{Myr}$ of voluminous explosive volcanism. Postignimbrite lavas are also exposed in several locations. Evidence for normal- $\delta^{18} \mathrm{O}$ rhyolite production, a requirement for the cannibalism model, remains unknown in the CSRP.

2. Cyclical patterns between normal and $\delta^{18} \mathrm{O}$ depleted rhyolites at any given location do not occur in the CSRP, nor do temporal patterns in the degree of depletion.

3. The overall $\delta^{18} \mathrm{O}$ depletion seen in the Yellowstone-Heise rhyolites is considerably less than that observed in the CSRP rhyolites. When volume-weighted across the entire eruptive output, the overall $\delta^{18} \mathrm{O}$ value at YellowstoneHeise is approximately $5.3 \%$, representing a modest depletion below that of "normal"- $\delta^{18} \mathrm{O}$ rhyolites $(6-8 \%)$. The overall volume-weighted $\delta^{18} \mathrm{O}$ value seen in the CSRP rhyolites is $\sim 2.4 \%$. This corresponds to a level of ${ }^{18} \mathrm{O}$ depletion rarely seen in even the most extreme low- $\delta{ }^{18} \mathrm{O}$ magmas outside the CSRP described to date.

\section{Pre-existing source model}

A second model for the origin of low- $\delta^{18} \mathrm{O}$ rhyolites in the CSRP involves the melting of a hydrothermally altered, low- $\delta{ }^{18} \mathrm{O}$ pre-existing source. Boroughs et al. (2005, 2012a) invoked a protolith altered prior to hotspot volcanism, namely, the hydrothermally altered material of the voluminous Idaho Batholith. Eocene hydrothermal alteration is well documented in several areas of the batholith and affects large volumes of granitic crust in zones $>2 \mathrm{~km}$ in depth and spanning $\sim 7,500 \mathrm{~km}^{2}$ (Criss and Taylor 1983; Criss et al. 1984). Although the model of Boroughs et al. $(2005,2012 \mathrm{a})$ is unlikely to be applicable to the low- $\delta^{18} \mathrm{O}$ rhyolites of the Yellowstone-Heise system, as is discussed in the following text, it appears to explain the rhyolites of the CSRP for the following reasons:
1. The hydrothermally altered granitoid bodies are exposed in a swath that projects beneath the SRP to coincide exactly with the extent of low- $\delta^{18} \mathrm{O}$ CSRP rhyolite exposures (Fig. 11). East of the projection of the eastern margin of the batholith beneath the SRP, the character of the rhyolites changes markedly; they become lower-T and are more chemically and isotopically variable (Hughes and McCurry 2002). Boroughs et al. (2012a) argue that this is due to an eastward change from batholith (partly hydrothermally altered to low- $\delta^{18} \mathrm{O}$ rock) to non-batholith (not hydrothermally altered and therefore normal- or high- $\delta^{18} \mathrm{O}$ ) crustal source rocks for rhyolitic magmatism.

2. A pre-existing, ancient hydrothermally altered source material would explain the CSRP's lack of an orderly $\delta^{18} \mathrm{O}$ progression as seen in the Yellowstone-Heise rhyolites (e.g. cyclic large normal to small low to large normal eruptions). Although it is possible that the "normal- $\delta{ }^{18} \mathrm{O}$ " component in the CSRP could remain hidden in the subsurface, the water-rock ratios calculated for Yellowstone-Heise suggest thermal budgets requiring $\sim 75 \%$ normal- $\delta^{18} \mathrm{O}$ rhyolite. If similar cannibalism was operating in the CSRP, $\sim 30,000-90,000 \mathrm{~km}^{3}$ of isotopically normal rhyolite would be required to be hidden in the subsurface.

3. The ubiquitously low- $-\delta^{18} \mathrm{O}$ values ( -1.2 to $4.8 \%$, volumeweighted average $=2.4 \%$ ) in the CSRP and the lack of normal- $\delta \delta^{18} \mathrm{O}$ rhyolite require a volumetrically significant protolith to be hydrothermally altered. Boroughs et al. (2012a) conservatively model the heat necessary to induce hydrothermal alteration of the source and find that it is of the same order as that necessary to melt the source to produce rhyolites. In other words, when applied to the CSRP, the cannibalism model requires double the mantle heat input of the pre-existing source model per gram of rhyolite produced. The pre-existing source model shifts the dramatic thermal burden of pervasive hydrothermal alteration to an earlier well-documented magmatic and hydrothermal episode, i.e., Eocene magmatism in the Idaho batholith.

\section{CSRP rhyolite genesis}

Numerous models exist to explain the genesis of rhyolite in the CSRP (Hughes and McCurry 2002; Cathey and Nash 2004; Boroughs et al. 2005; 2012a, b; Christiansen and McCurry 2008; Bonnichsen et al. 2008; Leeman et al. 2008; 2009; McCurry and Rodgers 2009). On the one hand, the pervasive low- $\delta{ }^{18} \mathrm{O}$ character of the rhyolites requires major assimilation of hydrothermally altered crustal material. On the other hand, several workers have pointed to the similarity of ${ }^{144} \mathrm{Nd} /{ }^{143} \mathrm{Nd}$ between the rhyolites and the basalts of the CSRP, which would seem to support a major role for fractional crystallisation 
in the evolution of the rhyolites with only limited assimilation of crust (Christiansen and McCurry 2008; McCurry and Rodgers 2009). This conflict between radiogenic and stable isotopic evidence for petrogenesis has been termed the ' $\mathrm{Nd}-\mathrm{O}$ paradox' (McCurry and Rodgers 2009). The following attempts have been made to reconcile the paradox:

1. Rhyolites evolve by fractional crystallisation and/or melting of young mafic sills emplaced in the deep crust and subsequently experience the 'cannibalisation' process to lower $\delta^{18} \mathrm{O}$. The difficulty here is that, as discussed earlier, the cannibalisation model is inconsistent with the geology and geochemistry of CSRP rhyolites.

2. Rhyolites are produced by melting of young mafic sills in the mid-crust that have themselves experienced hydrothermal alteration between emplacement and re-melting (Leeman et al. 2008). The problem with this model is that a particular, near-inflexible combination of parameters (the "sweet spot") must be exactly and repeatedly reproduced for genesis of low- $\delta^{18} \mathrm{O}$ rhyolite over a 6-Myr period.

3. The mantle-derived basaltic magma providing the heat to melt the crust is not represented by the SRP basalts, which are themselves contaminated by cratonic material. Basalt more closely resembling the isotopically more primitive Steens or Imnaha Basalts (Camp and Hanan 2008; Wolff et al. 2008) instead rises into the crust and interacts with it in different ways to produce either SRP basalts or rhyolites. This is supported by the observation that the CSRP rhyolites bear closer radiogenic isotopic similarity to the granites of the Idaho batholith than they do to contemporaneous basalts (Boroughs et al. 2012b). It should be noted that this hypothesis remains controversial.

In addition, we note that the so-called paradox only arises if similar $\mathrm{Nd}$ isotopic ratios of rhyolite and basalt require a close genetic relationship. Clearly, this is not so. The lack of knowledge about the crustal structure and isotopic composition of materials underlying the CSRP places limits on the efficacy of isotopic models, with the available data permissive of a wide variety of assimilants. Indeed two models using the same $\mathrm{Nd}$ isotopic data place the crustal component of the CSRP rhyolites between 30 and $70 \%$ (Nash et al. 2006) and less than $40 \%$ (McCurry and Rodgers 2009).

Prior to eruption, rhyolitic magmas appear to be stored as physically discrete batches as revealed by the multiple compositions of pyroxenes and glass which are present in a single hand specimen (Cathey and Nash 2004). Crystal aggregates in the same samples may contain all the pyroxene compositions observed in single crystals, but interestingly only a single composition of pigeonite and augite occur within any one aggregate (Cathey and Nash 2009; Ellis and Wolff 2012). Interestingly, while the ignimbrite may (or may not) contain multiple compositions of pyroxene, lavas appear to contain unimodal populations of pigeonite and augite.

\section{Future directions}

Despite progress made in recent years, a first-order goal for future work in the CSRP remains to generate a comprehensive, regionally coherent stratigraphy for the province to allow understanding of eruptive flux over time and recurrence intervals between eruptions. Currently, some regions are relatively well characterised (e.g. the Bruneau Jarbidge region, Bonnichsen 1982a; Cathey and Nash 2004), whereas others such as the area to the east of the Cassia Mountains between the CSRP and the Heise eruptive centre are only beginning to be investigated (Konstantinou et al. 2012). Volcanism from this period has been recognised in the ashfall record in basins in eastern Idaho and Wyoming (Anders et al. 2009) and across Utah and Nevada in more distal locations (Nash et al. 2006). It is of interest because it represents the boundary (be it sharp or diffuse) between the Snake Rivertype association of lithofacies which dominate the central Snake River Plain (Branney et al. 2008) and the more 'common rhyolite'-like lithofacies of the Heise and Yellowstone deposits (Christiansen 2001; Hughes and McCurry 2002; Morgan and McIntosh 2005). This poorly known zone also includes the boundary between the exclusively low- $\delta{ }^{18} \mathrm{O}$ rhyolites of the CSRP and the variably normal- and low- $\delta{ }^{18} \mathrm{O}$ rhyolites of the younger volcanics (see prior discussion). To develop a stratigraphic framework and understand the nature of correlations both along the margins of and across the SRP, geochemical characterisation of the volcanic stratigraphy is required (e.g. Perkins et al. 1995; Cathey and Nash 2004; Ellis et al. 2012a). This work also requires highprecision geochronology via either ${ }^{40} \mathrm{Ar} /{ }^{39} \mathrm{Ar}$ (e.g. Ellis et al. $2012 \mathrm{~b}$ ) or $\mathrm{U} / \mathrm{Pb}$ isotope dilution thermal ionisation mass spectrometry (e.g. Crowley et al. 2007). For the younger units in the CSRP, sanidine is absent to rare, disallowing the highest possible precision via the ${ }^{40} \mathrm{Ar} /{ }^{39} \mathrm{Ar}$ technique. To discriminate between magma batches, resolution on timescales of tens of thousands of years may be necessary to distinguish closely spaced eruptions and to investigate subtle crystal inheritance in the magmas.

Recently, following the successful completion of scientific drilling within the CSRP (project HOTSPOT http://www. usu.edu/geo/shervais/Shervais-USU-Geology/Project_Hotspot. $\mathrm{html}$ ), a new record of hotspot volcanism should be available from proximal regions. Two drill holes reaching $2 \mathrm{~km}$ in depth have provided rhyolitic successions which likely represent intra-caldera equivalents to the stratigraphies exposed on the margins of the CSRP. Detailed petrologic, geochemical, isotopic and geochronological study of the drill core will provide information, allowing more accurate volumes to be calculated for the explosive eruptions and to determine whether smallvolume lava domes exist within the centre of the plain, as typical of other caldera complexes. In addition, core materials (including basalts, rhyolites and interfingered sedimentary 
deposits) from other boreholes in the eastern Snake River Plain have yet to be maximised in terms of their scientific value, although some work towards this end has begun (McCurry and Rodgers 2009).

Acknowledgments Snake River Plain research at Washington State University has been generously funded by NSF (EAR0610081 and EAR0911457), and in the UK funding from NERC (NER/S/A/2004/ 12340 ) is gratefully acknowledged. Our work in the SRP has benefitted greatly from a discussion with numerous collaborators including Bill Leeman, Mike Branney, Graham Andrews, Ilya Bindeman, Mike McCurry, Barbara Nash, Henny Cathey, John Kauffman, Eric Christiansen, Matt Brueseke, and Marty Godchaux, although they may not agree with all (or indeed any) of our conclusions. We would like to thank the Bulletin of Volcanology for the invitation to submit this paper and the editorial assistance (and patience) from Steve Self. Graham Andrews and Henny Cathey were kind enough to provide informal reviews, and Matt Brueseke and Barbara Nash are thanked for their careful journal reviews.

\section{References}

Almeev RR, Bolte T, Nash BP, Holtz F, Erdmann M, Cathey HE (2012) High-temperature, low- $\mathrm{H}_{2} \mathrm{O}$ silicic magmas of the Yellowstone hotspot: an experimental study of rhyolite from the BruneauJarbidge Eruptive Center, Central Snake River Plain, USA. J Petrol 53(9):1837-1866

Anders M, Saltzman J, Hemming SJ (2009) Neogene tephra correlations in eastern Idaho and Wyoming: implications for Yellowstone hotspot-related volcanism and tectonic activity. Geol Soc Am Bull 121(5-6):837-856. doi:10.1130/B26300.1

Andrews GDM, Branney MJ (2011) Emplacement and rheomorphic deformation of a large, lava-like rhyolitic ignimbrite: Grey's Landing, southern Idaho. Geol Soc Am Bull 123:725-743. doi:10.1130/ B30167.1

Andrews GDM, Branney MJ, Bonnichsen B, McCurry M (2008) Rhyolitic ignimbrites in the Rogerson Graben, southern Snake River Plain volcanic province: volcanic stratigraphy, eruption history and basin evolution. Bull Volcanol 70(3):269-291. doi:10.1007/ s00445-007-0139-0

Armstrong RL, Leeman WP, Malde HE (1975) K-Ar dating of quaternary and neogene volcanic rocks of the Snake River Plain, Idaho. Am J Sci 275:225-251

Armstrong RL, Taubnek WH, Hales PO (1977) Rb-Sr and K-Ar geochronometry of Mesozoic granitic rocks and their $\mathrm{Sr}$ isotopic composition, Oregon, Washington, and Idaho. Geol Soc Am Bull 88:397-411

Bachmann O, Dungan MA, Lipman PW (2002) The Fish Canyon Magma Body San Juan Volcanic Field, Colorado: rejuvenation and eruption of an upper crustal batholith. J Petrol 43(8):1469-1503

Bernt J, Bonnichsen B (1982) Pre-Cougar Point Tuff volcanic rocks near the Idaho-Nevada border, Owyhee County, Idaho. Idaho Bur Mines Geol Bull 26:321-330, In: Bonnichsen B, Breckenridge RM (eds), Cenozoic geology of Idaho

Bindeman IN, Valley JW (2001) Low- $\delta 180$ rhyolites from Yellowstone; magmatic evolution based on analyses of zircons and individual phenocrysts. J Petrol 42:1491-1517

Bindeman IN, Watts KE, Schmitt AK, Morgan LA, Shanks PWC (2007) Voluminous low $\delta^{18} \mathrm{O}$ magmas in the late Miocene Heise Volcanic Field, Idaho: implications for the fate of Yellowstone hotspot calderas. Geology 35(11):1019-1022. doi:10.1130/G24141A.1
Bindeman IN, Fu B, Kita NT, Valley JW (2008) Origin and evolution of silicic magmatism at Yellowstone based on ion microprobe analysis of isotopically zoned zircons. J Petrol 49:163-193

Bonnichsen B (1982) The Bruneau-Jarbidge eruptive center; Southwestern Idaho. Idaho Bur Min Geol Bull 26:237-254, In: Bonnichsen B, Breckenridge RM (eds) Cenozoic geology of Idaho

Bonnichsen B (1982b) Rhyolite lava flows in the Bruneau-Jarbidge Eruptive Centre, southwestern Idaho. In: Bonnichsen B, Breckenridge RM (eds) Cenozoic geology of Idaho. Idaho Bur Mines Geol Bull 26:283-320

Bonnichsen B, Citron GP (1982) The Cougar Point Tuff, southwestern Idaho. Idaho Bur Mines Geol Bull 26:255-281, In: Bonnichsen B, Breckenridge RM (eds) Cenozoic geology of Idaho

Bonnichsen B, Godchaux MM (2002) Late Miocene, Pliocene, and Pleistocene geology of southwestern Idaho with emphasis on basalts in the Bruneau-Jarbidge, Twin Falls, and western Snake River Plain regions. In: Bonnichsen $\mathrm{B}$, White $\mathrm{CM}$, McCurry M (eds) Tectonic and magmatic evolution of the Snake River Plain volcanic province. Idaho Geol Surv Bull 30:233-312

Bonnichsen B, Kauffman DF (1987) Physical features of rhyolite lava flows in the Snake River Plain volcanic province, Southwestern Idaho. Geol Soc Am 212:119-145, Special Paper

Bonnichsen B, Leeman WP, Honjo N, McIntosh WC, Godchaux MM (2008) Miocene silicic volcanism in southwestern Idaho: geochronology, geochemistry, and evolution of the central Snake River Plain. Bull Volcanol 70:315-342. doi:10.1007/s00445-007-0141-6

Boroughs S, Wolff J, Bonnichsen B, Godchaux M, Larson P (2005) Large-volume, low $-\delta^{18} \mathrm{O}$ rhyolites of the central Snake River Plain, Idaho, USA. Geology 33:821-824. doi:10.1130/G21723.1

Boroughs S, Wolff JA, Bonnichsen B, Ellis BS, Larson P (2012a) Evaluating models of the origin of Miocene low $-\delta^{18} \mathrm{O}$ rhyolites of the Yellowstone/Columbia River large igneous province. Earth Plan Sci Lett 313-314:45-55

Boroughs S, Wolff JA, Starkel WA (2012b) A simple petrogenetic model for the formation of Miocene low- $\delta^{18} \mathrm{O}$ rhyolites of the Yellowstone Hotspot track, USA. AGU Fall Meeting San Francisco DI51A-2342

Brand BD, White CM (2007) Origin and stratigraphy of phreatomagmatic deposits at the Pleistocene Sinker Butte Volcano, Western Snake River Plain, Idaho. J Volcanol Geotherm Res 160:319-339

Branney MJ, Barry TL, Godchaux M (2004) Sheathfolds in rheomorphic ignimbrites. Bull Volcanol 66:485-491

Branney MJ, Bonnichsen B, Andrews GDM, Ellis B, Barry TL, McCurry M (2008) 'Snake River (SR) -type' volcanism at the Yellowstone hotspot track: distinctive products from unusual, high-temperature silicic super-eruptions. Bull Volcanol 70:293314. doi:10.1007/s00445-007-0140-7

Brueseke ME, Hart WK (2009) Intermediate composition magma production in an intracontinental setting: unusual andesites and dacites of the mid-Miocene Santa Rosa-Calico volcanic field, northern Nevada. J Volcanol Geotherm Res 188:197-213

Brueseke ME, Hart WK, Heizler MT (2008) Diverse mid-Miocene silicic volcanism associated with the Yellowstone-Newberry thermal anomaly. Bull Volcanol 70:343-360

Camp VE (1995) Mid-Miocene propagation of the Yellowstone mantle plume head beneath the Columbia River basalt source region. Geology 23:435-438

Camp VE, Hanan BB (2008) A plume-triggered delamination origin for the Columbia River basalt group. Geosph 4:480-495

Camp VE, Ross ME (2004) Mantle dynamics and genesis of mafic magmatism in the intermontane Pacific Northwest. J Geophys Res 109, B08204. doi:10.1029/2003JB002838

Carlson RW, Hart WK (1988) Flood basalt volcanism in the northwestern United States. In: Macdougall JD (ed) Continental flood basalts. Kluwer Academic Publishers, Dordrecht, pp 35-62

Cathey HE, Nash BP (2004) The Cougar Point Tuff: implications for thermochemical zonation and longevity of high-temperature, large- 
volume silicic magmas of the Miocene Yellowstone hotspot. J Petrol 45:27-58. doi:10.1093/petrology/egg081

Cathey HE, Nash BP (2009) Pyroxene thermometry of rhyolite lavas of the Bruneau-Jarbidge eruptive center, Central Snake River Plain. J Volcanol Geotherm Res 188(1-3):173-185

Cathey HE, Nash BP, Allen CM, Camphell IH, Valley JW, Kita N (2008) U-Pb zircon geochronology and Ti-in-zircon thermometry of large-volume low $\delta^{18} \mathrm{O}$ magmas of the Miocene Yellowstone hotspot. Geochim Cosmochim Acta 72:A143

Christiansen RL (2001) The Quaternary and Pliocene Yellowstone plateau volcanic field of Wyoming, Idaho, and Montana. U.S. Geol Sur Prof Paper 729-G, 145 p

Christiansen EH, McCurry M (2008) Contrasting origins of Cenozoic silicic volcanic rocks from the western Cordillera of the United States. Bull Volcanol 70:251-267

Christiansen RL, Foulger GR, Evans JR (2002) Upper mantle origin of the Yellowstone hotspot. Geol Soc Am Bull 114(10):1245-1256

Coble MA, Mahood GA (2012) Initial impingement of the Yellowstone plume located by widespread silicic volcanism contemporaneous with Columbia River flood basalts. Geology 40:655-658

Criss RJ, Taylor HP (1983) An ${ }^{18} \mathrm{O} /{ }^{16} \mathrm{O}$ and $\mathrm{D} / \mathrm{H}$ study of Tertiary hydrothermal systems in the southern half of the Idaho Batholith. Geol Soc Am Bull 94(5):640-663

Criss RJ, Ekren EB, Hardyman RF (1984) Casto ring zone; a 4,500-km² fossil hydrothermal system in the Challis volcanic field, central Idaho. Geology 12:331-334

Crowley JL, Schoene B, Bowring SA (2007) U-Pb dating of zircon in the Bishop Tuff at the millennial scale. Geology 35:1123-1126

Davidson JP, Morgan DJ, Charlier BLA, Harlou R, Hora JM (2007) Microsampling and isotopic analysis of igneous rocks: implications for the study of magmatic systems. Ann Rev Earth Plan Sci $35: 273-311$

Davis OK, Ellis B (2010) Early occurrence of sagebrush steppe, Miocene (12 Ma) on the Snake River Plain. Rev Palaeobot Palynol 160:172-180

Ellis B, Branney MJ (2010) Silicic phreatomagmatism in the Snake River Plain: the Deadeye Member. Bull Volcanol 72(10):1241-1257. doi:10.1007/s00445-010-0400-9

Ellis BS, Wolff JA (2012) Complex storage of rhyolite in the central Snake River Plain. J Volcanol Geotherm Res 211-212:1-11

Ellis BS, Barry TL, Branney MJ, Wolff JA, Bindeman I, Wilson R, Bonnichsen B (2010) Petrologic constraints on the development of a large-volume, high temperature, silicic magma system: the Twin Falls eruptive centre, central Snake River Plain. Lithos 120:475489. doi:10.1016/j.lithos.2010.09.008

Ellis BS, Branney MJ, Barry TL, Barfod D, Bindeman I, Wolff JA, Bonnichsen B (2012a) Geochemical correlation of three largevolume ignimbrites from the Yellowstone hotspot track, Idaho, USA. Bull Volcanol 74:261-277

Ellis BS, Mark DF, Pritchard CJ, Wolff JA (2012b) Temporal dissection of the Huckleberry Ridge Tuff using the ${ }^{40} \mathrm{Ar} /{ }^{39} \mathrm{Ar}$ dating technique. Qua Geochron 9:34-41

Fleck RJ, Criss RE (1985) Strontium and oxygen isotopic variations in Mesozoic and Tertiary plutons of central Idaho. Contrib Mineral Petrol 90:291-308

Fleck RJ, Criss RE (2004) Location, age, and tectonic significance of the Western Idaho Suture Zone (WISZ). Open-File Report-US Geol Surv

Gaschnig RM, Vervoort JD, Lewis RS, Tikoff B (2011) Isotopic evolution of the Idaho batholith and challis intrusive province, Northern US Cordillera. J Petrol 52:2397-2429. doi:10.1093/ petrology/egr050

Geist D, Richards MA (1993) Origin of the Columbia plateau and the Snake River Plain: deflection of the Yellowstone plume. Geology 21:789-792

Giordano D, Russell JK, Dingwell DB (2008) Viscosity of magmatic liquids: a model. Earth Plan Sci Lett 271:123-134
Godchaux MM, Bonnichsen B (2002) Syneruptive magma-water and posteruptive lava-water interactions in the Western Snake River Plain, Idaho, during the past 12 million years. In: Bonnichsen B, White CM, McCurry M (eds) Tectonic and magmatic evolution of the Snake River Plain volcanic province. Idaho Geol Surv Bull 30:387-434

Godchaux MM, Bonnichsen B, Jenks MD (1992) Types of phreatomagmatic volcanoes in the western Snake River Plain, Idaho, USA. J Volcanol Geotherm Res 52(1-3):1-25

Hales TC, Abt DL, Humphreys ED, Roering JJ (2005) Delamination origin for the Columbia River flood basalts and Wallowa Mountain uplift in NE Oregon, U.S.A. Nature 438(8):842-845. doi:10.1038/ nature 04313

Henry CD, Wolff JA (1992) Distinguishing strongly rheomorphic tuffs from extensive silicic lavas. Bull Volcanol 54:171-186

Henry CD, Castor SB, McIntosh WC, Heizler MT, Cuney M, Chemillac $\mathrm{R}$ (2006) Timing of oldest Steens basalt magmatism from precise dating of silicic volcanic rocks, McDermitt caldera and northwest Nevada Volcanic Field. Eos Transactions AGU 87 (52)

Hildreth W (1979) The BishopTuff: evidence for the origin of compositional zonation in silicic magma chambers. In: Chapin CE, Elston WE (eds) Ash-flow tuffs. Geol Soc Am, Special Paper 180, 43-75

Hildreth W (1981) Gradients in silicic magma chambers: implications for lithospheric magmatism. J Geophys Res 86:10153-10192

Hildreth W, Wilson CJN (2007) Compositional zoning of the Bishop Tuff. J Petrol 48(5):951-999

Hill M, Schmitz MD (2011) Processes of magma evolution and crystal recycling recorded in zircon populations of large volume rhyolites in the western Mount Bennett Hills, Central Snake River Plain, Idaho, and the implications for constraining the pre- and syn- eruptive evolution of silicic magmas. Geol Soc Am Abstr Prog 43(4):64

Honjo N, Leeman WP (1987) Origin of hybrid ferrolatite lavas from the Magic Reservoir eruptive centre, Snake River Plain, Idaho. Contrib Mineral Petrol 96:163-173

Honjo N, Bonnichsen B, Leeman WP, Stormer JC (1992) Mineralogy and geothermometry of high-temperature rhyolites from the central and western Snake River Plain. Bull Volcanol 54:220-237

Hooper PR, Binger GB, Lees KR (2002) Ages of the Steens and Columbia River flood basalts and their relationship to extensionrelated calc-alkalic volcanism in eastern Oregon. Geol Soc Am Bull 114:43-50

Hooper PR, Camp VE, Reidel SP, Ross ME (2007) The origin of the Columbia River Flood Basalt province: plume versus non-plume models. In: Foulger, G. and Jurdy (eds) Plates, plumes and planetary processes. Geol Soc Am Spec Pap 430:635-668

Hughes SS, McCurry M (2002) Bulk major and trace element evidence for a time-space evolution of Snake river Plain rhyolites, Idaho. In: Bonnichsen B, White CM, McCurryM (eds) Tectonic and magmatic evolution of the Snake River Plain volcanic province, vol. 30. Idaho Geological Survey Bulletin, pp. 161-176

James DE, Fouch MJ, Carlson RW, Roth JB (2011) Slab fragmentation, edge flow and the origin of the Yellowstone hotspot track. Earth Plan Sci Lett 311:124-135

Jarboe NA, Coe RS, Renne PR, Glen JM, Maniken EA (2008) Quickly erupted volcanic sections of the Steens Basalt, Columbia River Basalt Group: Secular variation, tectonic rotation, and the Steens Mountain reversal. Geochem Geophys Geosyst 9, Q11010. doi:10. 1029/2008GC002067

Jarboe NA, Coe RS, Renne PR, Glen JM (2010) The age of the Steens reversal and the Columbia River Basalt Group. Chem Geol 274:158-168

Jenks MD, Bonnichsen B (1989) Subaqueous basalt eruptions into Pliocene Lake Idaho, Snake River Plain, Idaho. In: Chamberlain VE, Breckenridge RM, Bonnichsen B (eds) Guidebook to the geology of Northern and Western Idaho and surrounding area. Idaho Geol Surv Bull 28:17-34 
Jordan BT, Grunder AL, Duncan RA, Deino AL (2004) Geochronology of age-progressive volcanism of the Oregon High Plains: implications for the plume interpretation of Yellowstone. J Geophys Res 109:B10202-B10221

Kellogg KS, Harlan SS, Mehnert HH, Snee LW, Pierce KL, Hackett WR, Rogers DW (1994) Major 10.2 Ma rhyolitic volcanism in the eastern Snake River Plain, Idaho-isotopic age and stratigraphic setting of the Arbon Valley Tuff member of the starlight formation. US Geol Surv Bull 2091:18

Kiilsgaard TH, Lewis RS, Bennett EH (2001) Plutonic and hypabyssal rocks of the Hailey $1^{\circ} \times 2^{\circ}$ Quadrangle, Idaho. US Geol Surv Bull 2064-U

Knesel KM, Davidson JP, Duffield WA (1999) Evolution of silicic magma through assimilation and subsequent recharge: evidence from $\mathrm{Sr}$ isotopes in sanidine phenocrysts, Taylor Creek Rhyolite, NM. J Petrol 40:773-786. doi:10.1093/petrology/40.5.773

Konstantinou A, Strickland A, Miller EL, Wooden JW (2012) Multi-stage Cenozoic extension of the Albion-Raft River-Grouse Creek metamorphic core complex: geochronologic and stratigraphicconstraints. Geosphere 8:1429-1466

Lavallée Y, de Silva SL, Salas G, Byrnes JM (2006) Explosive volcanism (VEI 6) without caldera formation: insight from Huaynaputina volcano, southern Peru. Bull Volcanol 68:333-348

Leeman WP (1982) Geology of the Magic Reservoir area, Snake River Plain. In: Bonnichsen B, Breckenridge RM (eds) Cenozoic geology of Idaho. Idaho Bur Mines Geol Bull 26:369-376

Leeman WP, Menzies MA, Matty DJ, Embree GF (1985) Strontium, neodymium and lead isotopic compositions of deep crustal xenoliths from the Snake River plain: evidence for Archean basement. Earth Planet Sci Lett 75:354-368

Leeman WP, Annen C, Dufek J (2008) Snake River Plain-Yellowstone silicic volcanism: implications for magma genesis and magma fluxes. Geol Soc Lond Spec Publ 304:235-259. doi:10.1144/ SP304.12

Leeman WP, Schutt DL, Hughes SS (2009) Thermal structure beneath the Snake River Plain: implications for the Yellowstone hotspot. J Volcanol Geotherm Res 188(1-3):57-67. doi:10.1016/j.jvolgeores. 2009.01.034

Lipman PW (1976) Caldera collapse breccias in the western San Juan Mountains, Colorado. Geol Soc Am Bull 87:1397-1410

Lipman PW (1997) Subsidence of ash-flow calderas: relation to caldera size and magma-chamber geometry. Bull Volcanol 59:198-218

Liu L, Stegman DR (2012) Origin of Columbia River flood basalt controlled by propagating rupture of the Farallon slab. Nature 482:386-389. doi:10.1038/nature10749

Long MD, Till CB, Druken KA, Carlson RW, Wagner LS, Fouch MJ, James DE, Grove TL, Schmerr N, Kincaid C (2012) Mantle dynamics beneath the Pacific Northwest and the generation of voluminous back-arc volcanism. Geochem Geophys Geosyst 13:Q0AN01. doi:10.1029/2012GC004189

Lowenstern JB, Hurwitz SH (2008) Monitoring a supervolcano in repose: heat and volatile flux at the Yellowstone caldera. Elements 4:35-40

Malde HE, Powers HA (1962) Upper Cenozoic stratigraphy of western Snake River Plain, Idaho. Geol Soc Am Bull 73:1197-1220

Manea VC, Manea M, Leeman WP, Schutt DL (2009) The influence of plume head-lithosphere interaction on magmatism associated with the Yellowstone hotspot track. J Volcanol Geotherm Res 188(13):68-85. doi:10.1016/j.jvolgeores.2008.12.012

McCurry M, Rodgers DW (2009) Mass transfer along the Yellowstone hotspot track I: petrologic constraints on the volume of mantlederived magma. J Volcanol Geotherm Res 188:86-98

McDonough WC, Sun S-S (1995) The composition of the Earth. Chem Geol 120(3-4):223-253

Morgan LA, McIntosh WC (2005) Timing and development of the Heise volcanic field, Snake River Plain, Idaho, western USA. Geol Soc Am Bull 117:288-306. doi:10.1130/B25519.1
Nash BP, Perkins ME (2012) Neogene fallout tuffs from the Yellowstone hotspot in the Columbia plateau region, Oregon, Washington and Idaho, USA. PLoS One 7(10):e44205

Nash BP, Perkins ME, Christensen JN, Lee DC, Halliday AN (2006) The Yellowstone hotspot in space and time: $\mathrm{Nd}$ and $\mathrm{Hf}$ isotopes in silicic magmas. Earth Plan Sci Lett 247:143-156

Obrebski M, Allen RM, Xue M, Hung S (2010) Slab-plume interaction beneath the Pacific Northwest. Geophys Res Lett 37, L14305. doi:10.1029/2010GL043489

Perkins ME, Nash BP (2002) Explosive silicic volcanism of the Yellowstone hotspot: the ash fall tuff record. Geol Soc Am Bull 114:367-381

Perkins ME, Nash WP, Brown FH, Fleck RJ (1995) Fallout tuffs of Trapper Creek Idaho - a record of Miocene explosive volcanism in the Snake River Plain volcanic province. Geol Soc Am Bull 107:1484-1506

Perkins ME, Williams SK, Brown FH, Nash WP, McIntosh W (1998) Sequence, age, and source of silicic fallout tuffs in middle to late Miocene basins of the northern Basin and Range Province. Geol Soc Am Bull 110:344-360

Perry FV, DePaolo DJ, Baldridge WS (1993) Neodymium isotopic evidence for decreasing crustal contributions to Cenozoic ignimbrites of the western United States: implications for the thermal evolution of the Cordilleran crust. Geol Soc Am Bull 105:872-882

Pierce KL, Morgan LA (1992) The track of the Yellowstone hotspot: volcanism, faulting and uplift. In: Link PK, Kuntz MA, Platt LB (eds) Regional geology of eastern Idaho and western Wyoming. Geol Soc Am Mem 179:1-53

Ramos FC, Wolff JA, Tollstrup DL (2005) Sr isotope disequilibrium in Columbia River flood basalts: evidence for rapid, shallow-level, open-system processes. Geology 33:457-460

Reidel SP, Camp VE, Tolan TL, Martin BS (2013) The Columbia River flood basalt province: stratigraphy, areal extent, volume, and physical volcanology. In: Reidel SP, Camp VE, Ross ME, Wolff JA, Martin BS, Tolan TL, Wells RE (eds) The Columbia River flood basalt province: geological society of America special paper 497, pp 1-43. doi:10.1130/2013.2497(01)

Rodgers DW, McCurry M (2009) Mass transfer along the Yellowstone hotspot track II: kinematic constraints on the volume of mantle-derived magma. J Volcanol Geotherm Res 188(1-3):99-107

Rose WI, Riley CM, Darteville S (2003) Sizes and shapes of $10 \mathrm{Ma}$ distal fall pyroclasts in the Ogallala Group, Nebraska. J Geol 111:115-124

Schmandt B, Dueker K, Humphreys E, Hansen S (2012) Hot mantle upwelling across the 660 beneath Yellowstone. Earth Plan Sci Lett 331-332:224-236

Schutt DL, Dueker K, Yuan H (2008) Crust and upper mantle velocity structure of the Yellowstone hot spot and surroundings. J Geophys Res 113, B03310. doi:10.1029/2007JB005109

Shervais JW, Hanan BB (2008) Lithospheric topography, tilted plumes, and the track of the Snake River-Yellowstone hot spot. Tectonics 27:TC5004

Smith RL (1979) Ash-flow magmatism. In: Chapin CE, \& Elston WE (eds) Ash-flow tuffs. Geological Society of America Special Paper 180, 5-28

Smith AD (1992) Back-arc convection model for Columbia River basalt genesis. Tectonophysics 207:269-285

Sparks RSJ, Francis PW, Hamer RD, Pankhurst RJ, O’Callaghan LO, Thorpe RS, Page R (1985) Ignimbrites of the Cerro Galan caldera, NW Argentina. J Volcanol Geotherm Res 24:205-248

Swanson DA, Wright TL, Hooper PR, Bentley RD, (1979) Revisions in stratigraphic nomenclature of the Columbia River Basalt Group. US Geol Surv Bull1457-G, 59 p

Swisher CC, Ach JA, Hart WK (1990) Laser fusion ${ }^{40} \mathrm{Ar} /{ }^{39} \mathrm{Ar}$ dating of the type Steens Mountain Basalt, southeastern Oregon and the age of the Steens geomagnetic polarity transition. Eos (Transactions, 
American Geophysical Union), v. 71, Fall Meeting Supplement, p. 1296

Taylor HP (1968) The oxygen isotope geochemistry of igneous rocks. Contrib Mineral Petrol 19:1-71

Taylor SR, McLennan SM (1985) The continental crust: its composition and evolution. Blackwell Science, Oxford

Wagner LS, Forsyth DW, Fouch MJ, James DE (2010) Detailed threedimensional shear wave velocity structure of the northwestern United States from Rayleigh wave tomography. Earth Plan Sci Lett 299:273-284. doi:10.1016/j.eps1.2010.09.005

Watts KE, Leeman WP, Bindeman IN, Larson PB (2010) Supereruptions of the Snake River Plain: two-stage derivation of low-18O rhyolites from normal- ${ }^{18} \mathrm{O}$ crust as constrained by Archean xenoliths. Geology 38:503-506

Watts KE, Bindeman IN, Schmitt A (2011) Large-volume rhyolite genesis in caldera complexes of the Snake River Plain: insights from the Kilgore Tuff of the Heise volcanic field, Idaho, with comparison to Yellowstone and Bruneau-Jarbidge rhyolites. J Petrol 52:857-890
Williams PL, Mytton JW, Covington HR, (1999) Geologic map of the Stricker 1 quadrangle, Cassia, Twin Falls, and Jerome Counties, Idaho. US Geol Surv Misc Inv Series Map I-2078 1:48,000

Wilson CJN, Blake S, Charlier BLA, Sutton AN (2006) The 26.5 ka Oruanui Eruption, Taupo Volcano, New Zealand: development, characteristics and evacuation of a large rhyolitic magma body. J Petrol 47(1):35-69

Wolff JA, Ramos FC, Hart GL, Patterson JD, Brandon AD (2008) Columbia River flood basalts from a centralized crustal magmatic system. Nat Geosci 1:177-180. doi:10.1038/ngeo124

Wolff JA, Ellis BS, Ramos FC (2011) Strontium isotopes and magma dynamics: insights from high-temperature rhyolites. Geology 39:931-934

Wright KE, McCurry M, Hughes SS (2002) Petrology and geochemistry of the Miocene tuff of McMullen Creek, central Snake River Plain. In: Bonnichsen B, McCurry M, White CM (eds) Tectonic and magmatic evolution of the Snake River Plain volcanic province. Idaho Geol Surv Bull 30:177-194

Yuan H, Dueker K (2005) P wave tomogram of the Yellowstone plume. Geophys Res Lett 32, L07304. doi:10.1029/2004GL022056 